\title{
54. EVIDENCE FOR TWO DISTINCT HYDROTHERMAL SYSTEMS IN THE GUAYMAS BASIN1
}

\author{
Miriam Kastner, Scripps Institution of Oceanography, La Jolla, California
}

\begin{abstract}
Mineralogical and oxygen isotopic analyses of samples from Deep Sea Drilling Project Sites 477, 481, and 477 in the Guaymas Basin indicate the existence of two distinct hydrothermal systems. In the first, at Sites 481 and 478 , hot dolerite sills intruded into highly porous hemipelagic siliceous mudstones that were moderately rich in organic matter, thermally altered the adjacent sediments, and expelled hydrothermal pore fluids. The second, at Site 477 and active at present, is most probably caused by a recent igneous intrusion forming a magma chamber at shallow depth.

In the first hydrothermal system, the main thermal reactions above and below the sills are dissolution of opal-A and formation of quartz, either directly or through opal-CT; formation of smectite; formation of analcime only above the sills; dissolution and recrystallization of calcite and occasional formation of dolomite or protodolomite. The $\delta^{18} \mathrm{O}$ values of the hydrothermally altered sediments range from 9.9 to $12.2 \%$ (SMOW). The $\delta^{18} \mathrm{O}$ values of recrystallized calcites above the first sill complex, Site 481 , indicate temperatures of $140^{\circ}$ to $170^{\circ} \mathrm{C}$. No fluid recharge is required in this system. The thickness of the sill complexes and the sequence and depth of intrusion into the sediment column determine the thickness of the alteration zones, which ranges from 2 or 3 to approximately 50 meters. Generally, the hydrothermally altered zone is thicker above than below the sill.

In the second type, the sediments are extensively recrystallized. The characteristic greenschist-facies mineral assemblage of quartz-albite-chlorite-epidote predominates. Considerable amounts of pyrite, pyrrhotite, and sphene are also present. The lowest $\delta^{18} \mathrm{O}$ value of the greenschist facies rocks is $6.6 \%$, and the highest $\delta^{18} \mathrm{O}$ value of the associated pore fluids is $+1.38 \%$ o (SMOW). The paragenesis and the oxygen isotopes of individual phases indicate alteration temperatures of $300 \pm 50^{\circ} \mathrm{C}$. On the basis of the oxygen isotopes of the solids and associated fluids, it is concluded that recharge of fluids is required. The water/rock ratio in wt. \% is moderate, approximately $2 / 1$ to $3 / 1-$ higher than the calculated water/rock ratio of the hydrothermal system at the East Pacific Rise, $21^{\circ} \mathrm{N}$.
\end{abstract}

\section{INTRODUCTION}

Oceanic spreading centers are sites of hydrothermal activity. Examples are the Red Sea deeps (Degens and Ross, 1969), the Galapagos Rift (Weiss et al., 1977; Corliss et al., 1979; Edmond et al., 1979a, b), and the East Pacific Rise (EPR) $21^{\circ} \mathrm{N}$ hydrothermal system (Spiess et al., 1980; Francheteau et al., 1979; Haymon and Kastner, 1981). Metal sulfides, silicates, and oxides are associated with these hydrothermal systems.

The Gulf of California, the closest western hemisphere analog to the Red Sea, is an intercontinental rift which consists of several basins that represent sea-floor spreading segments connected by transform faults (Moore, 1973; Sharman, 1976). The topographic features of the basins are masked by thick biogenic and terrigenous sediments (van Andel, 1964; Calvert, 1966). Sedimentation rates are between 1 and $2 \mathrm{~km} / \mathrm{m}$.y. This series of spreading centers and transform faults connects the EPR to the south with the structurally continuous Salton Trough to the north.

The Guaymas Basin, in the central Gulf of California, is approximately $240 \mathrm{~km}$ long and $60 \mathrm{~km}$ wide, and has two grabens approximately 200 meters deep and 3 to $5 \mathrm{~km}$ wide, which are offset by a transform fault that is $\sim 20 \mathrm{~km}$ long.

Oceanographic expeditions to the Gulf of California during the early seventies failed to find evidence for hydrothermal activity (Wilde et al., 1973). Extensive heat

\footnotetext{
${ }^{1}$ Curray, J. R., Moore, D. G., et al., Init. Repts. DSDP, 64: Washington (U.S. Govt. Printing Office).
}

flow surveys in the Guaymas Basin, which gave high and irregular heat flow values (Lawver et al., 1975; Lawver and Williams, 1979), suggested recent shallow igneous intrusions and possible hydrothermal activity. In 1977, ferromanganese-encrusted sulfide and talc deposits were recovered from the northern trough, Guaymas Basin (Lonsdale, 1978). Conductive heat flux in the vicinity of this deposit locally exceeds $30 \mu \mathrm{cal} / \mathrm{cm}^{2} \mathrm{~s}$ (Williams et al., 1979; Becker, 1981). Sulfur and oxygen isotopes indicated precipitation at about $280^{\circ} \mathrm{C}$ (Lonsdale et al., 1980). ${ }^{3} \mathrm{He} /{ }^{4} \mathrm{He} 65-70 \%$ higher than atmospheric helium were measured in the Guaymas Basin (Lupton, 1979); ${ }^{3} \mathrm{He}$ is a geochemical tracer for mantlederived volatiles. In 1978, during the survey cruise for DSDP Leg 64, gravity cores were recovered from the slopes and troughs of the Guaymas Basin. High manganese concentrations at the top of the cores from the grabens were observed. Kastner and Gieskes (1979) suggested a hydrothermal source for the observed manganese enrichment subsequent to Leg 64 . This was confirmed by the discovery of extensive hydrothermal vents and deposits in the southern graben (Lonsdale et al., in preparation).

During DSDP Leg 64, three sites were drilled in the Guaymas Basin: Site 477 in the southern graben in an area of heat flow higher than 20 heat-flow units (HFU); Site 481 in the northern graben with a heat flow of approximately $4 \mathrm{HFU}$ : and Site $478,12 \mathrm{~km}$ northwest of Site 477 on the basement floor, assumed to be adjacent to the transform fault, with a heat flow of $\sim 3.7 \mathrm{HFU}$. The crustal age at Site 478 is no older than $400 \mathrm{ky}$. At these three sites, the hemipelagic sediments were in- 
truded by basalt and dolerite sills of apparently very limited lateral extension. Although all the sill complexes penetrated were cold, the adjacent sediments indicate significant hydrothermal alteration. In addition, at Site 477 below the first sill complex, extensive high-temperature alteration of the sediments and the formation of greenschist facies rocks were observed, most probably in response to a young, shallow intrusion.

Detailed mineralogical, petrological, and oxygen isotopic analyses of the unaltered and altered sediments and oxygen isotopic analyses of the pore fluids were conducted. The data indicate the existence of two distinct hydrothermal systems in the Guaymas Basin: one is associated with the intrusions of the sills into highly porous hemipelagic sediments (Einsele et al., 1980); and the second is associated with the shallow magma chamber.

\section{METHODS}

Bulk sediments and various grain-size fractions ( $>63 \mu \mathrm{m}, 40-63$ $\mu \mathrm{m}, 2-40 \mu \mathrm{m},<2 \mu \mathrm{m}$, and when necessary $<1 \mu \mathrm{m}$ ) were analyzed by routine petrographic methods, X-ray diffraction, and scanning electron microscope with energy dispersive X-ray attachment. Oxygen isotope analyses of silicates were carried out by the $\mathrm{BrF}_{5}$ method described by Clayton and Mayeda (1963), of carbonates by the method of McCrea (1950), and of the pore fluid by the method of Epstein and Mayeda (1953). The isotopic results are reported in the conventional fashion as $\delta^{18} \mathrm{O}$ in per mil relative to Standard Mean Ocean Water (SMOW) (Craig, 1961). The experimental precision was $\pm 0.15 \%$ for hydrous silicates, $\pm 0.1 \%$ o for anhydrous silicates, $\pm 0.07 \%$ for carbonates, and $\pm 0.05 \%$ for pore fluids. Quartz from Site 477 was separated for oxygen isotope analysis by the sodium pyrosulfate method of Syers et al. (1968). Temperatures of formation were calculated, using the recalculated calcite-water oxygen isotope fractionation factor of O'Neil et al. (1969), using the $\mathrm{CO}_{2}-\mathrm{H}_{2} \mathrm{O}$ fractionation factor at $25^{\circ} \mathrm{C}$ of O'Neil et al. (1975), and the quartz-chlorite empirical equation of Wenner and Taylor (1971).

\section{LITHOLOGY AND MINERALOGY OF SITES 477, 481, AND 478}

The unaltered sediments of these three DSDP sites are similar. They are immature sediments, predominantly diatomaceous silty clays with occasional sandy layers at the base of the numerous turbidites. Diatomrich $(\sim 70 \%$ diatoms), several-centimeter-thick layers are common at the top of some turbidites. The average composition of the sediments is $30-50 \%$ diatoms, with some radiolarians and silicoflagellates, $30-45 \%$ detrital clay minerals, $10-15 \%$ calcareous nannofossils with some foraminifers, $4-15 \%$ feldspars, 3-10\% quartz, and $1-2 \%$ heavy minerals. Volcanic glass is present but not common. Pyrite is ubiquitous ( 1 to $<3 \%$ ) and concentrated within diatom frustules. Small amounts $(2-4 \%)$ of diagenetic clinoptilolite are common below 2-3 meters sub-bottom depth. Several intervals of laminated sediments were observed in Site 481 below 240 meters and in Site 478 below 300 meters, indicating a sedimentation regime similar to the prevailing regime at Site 480 (site chapter, this volume, Pt. 1).

The intrusion of basalt and dolerite sills into the sediments at all three sites resulted in extensive thermal reactions between the heated and chemically altered pore fluids and the various phases in the adjacent sediments (and to some extent within the sills). The following sequence of decreasing reactivity was observed:

opal-A $>$ opal-CT $\simeq$ smectite $\geq$ clinoptilolite $>$ illite $>$ chlorite $\simeq$ feldspar $>$ quartz, and dolomite $>$ calcite.

The shallow magma chamber at Site 477 and the associated hydrothermal system caused extensive recrystallization of almost the entire sediment column below the sill complex to greenschist facies rocks.

Because of multiple thermal events at each site, it is extremely difficult to study the sequence and rates of diagenetic reactions in the Guaymas Basin. Detailed mineralogical data of the original and hydrothermally altered sediments of DSDP Sites 477,481 , and 478, respectively, are given in Appendixes A, B, and C. Syntheses of the major mineral zones of these three sites, which are based on the data in the Appendix tables, are given in text Tables 1, 2, and 3 .

At Sites 481 and 478 , the thermal reactions were both quantitatively and qualitatively more extensive at the upper contact and between adjacent sill complexes than at their lower contact, as follows: The thermally affected zone is thicker above the sills, and the formation of well-crystallized smectite and even of illite and chlorite, as well as the formation of analcime and dolomite are observed only at the upper contacts and between the sill complexes.

At Site 477, however, the major heat source and hydrothermal system below the sill complex and not the sill itself are responsible for the well-crystallized smectite and the newly formed K-feldspars at this lower contact zone.

Above the average sills $(\sim 30 \mathrm{~m})$, opal-A was transformed directly to quartz, without an intermediate opalCT. Opal-CT formed only in sediments between two adjacent sill complexes-at Site 481 between the second and third sills and in Hole 478 between the first and second sills-and in sediments which were affected for relatively long times by an unusually thick sill complex $(>100 \mathrm{~m})$. In this latter case, the opal-CT forms above and most probably also below the sill contacts-for example, in Hole 478 in the sediments between the second sill and the thick third sill-quartz is the silica phase at the contact zone.

\section{OXYGEN ISOTOPES OF SOLIDS AND PORE FLUIDS}

Oxygen isotopes of the unaltered and thermally altered silicate fraction of the sediments of Sites 477 and 481 were analyzed. The carbonates were removed by Naacetate-acetic acid buffer solution prior to the extraction of oxygen from the silicates. The results are given in Table 4 and shown in Figures 1 and 2.

In both sites, the $\delta 18 \mathrm{O}$ values of the unaltered sediments above the shallowest sill vary greatly, between 14.5 and $27 \%$ (SMOW). The average $\delta^{18} \mathrm{O}$ value of these sediments is $17-20 \%$. The low values represent the bases of turbidites, which have higher ratios of quartz + feldspar to clay minerals + diatoms than the tops of the turbidites. Above and between adjacent sill complexes, the 
Table 1. Mineral zones in sediments at Site 477.

\begin{tabular}{|c|c|}
\hline $\begin{array}{l}\text { Sub-bottom } \\
\text { Depth }(\mathrm{m})\end{array}$ & Mineral Assemblage \\
\hline 0 to $\sim 32$ & $\begin{array}{l}\text { A mixture of the detrital minerals quartz, plagioclase, some alkali feldspar and the clay minerals mixed-layer smectite/illite, illite, } \\
\text { and chlorite/kaolinite with the biogenic minerals opal-A and calcite and with very small amounts of the diagenetic minerals clino- } \\
\text { ptilolite (first detected at } \sim 3 \mathrm{~m} \text { depth) and pyrite. }\end{array}$ \\
\hline 32 to -58 & $\begin{array}{l}\text { Thermally altered zone at upper contact with sill complex. Detrital plagioclase and quartz similar to zone above. Some newly form- } \\
\text { ed quartz, most probably from opal-A, the abundance of which diminishes rapidly toward the sill. By } 6 \text { to } 8 \text { meters above the sill } \\
\text { no opal-A can be detected. No opal-CT observed. Only traces of detrital clay minerals; instead, newly formed, well-crystallized } \\
\text { smectite increases in abundance toward the contact with the sill. The abundance of clinoptilolite diminishes toward the sill, and at } \\
-50 \text { meters depth analcime replaces clinoptilolite. Calcite is present in most samples but is absent below } \sim 50 \text { meters. It coexists } \\
\text { with some dolomite at } \sim 50 \text { meters; no dolomite below this depth. Some pyrite and gypsum are present, and possibly some } \\
\text { goethite. }\end{array}$ \\
\hline 58 to $\sim 105$ & Sill complex (in Hole $477 \mathrm{~A}$, the sill complex was encountered between 33 and $\sim 63 \mathrm{~m}$ depth) \\
\hline 105 to $\sim 120$ & $\begin{array}{l}\text { Thermally altered zone at lower contact with sill complex. This zone is also affected by the deeper-seated, active hydrothermal sys- } \\
\text { tem. Adjacent to the sill (between } 105 \text { and } \sim 110 \mathrm{~m} \text { ) only small amounts of detrital plagioclase and no opal-A or opal-CT, but } \\
\text { much quartz-a mixture of detrital and newly formed. } \\
\text { The active hydrothermal system below the sill is most probably responsible for the newly formed euhedral K-feldspar. Only traces } \\
\text { of detrital clay minerals; the main clay mineral is a well-crystallized smectite. No calcite but some protodolomite. Some pyrite, gyp- } \\
\text { sum, and anhydrite. } \\
\text { At } \sim 115 \mathrm{~m} \text { some opal-A and only traces of hydrothermal K-feldspar and smectite are present. Instead, much protodolomite has } \\
\text { been formed. Some pyrite, gypsum, and anhydrite are still present. This subinterval (approximately } 110-120 \mathrm{~m} \text { sub-bottom) is a } \\
\text { partially altered zone between the thermally altered zone at the lower contact with the sill complex and the deep-seated active hy- } \\
\text { drothermal system. } \\
\text { Clinoptilolite is absent throughout this depth interval. }\end{array}$ \\
\hline 120 to $\sim 267$ & Hydrothermally altered sediments. Opal-A is absent throughout this zone. There are four subzones: \\
\hline A) 120 to $\sim 160$ & $\begin{array}{l}\text { A mixture of detrital and newly formed quartz, detrital and albitized plagioclase, and a small amount of hydrothermal K-feldspar. } \\
\text { Only small amounts of detrital clay minerals are still present and the first newly formed chlorite appears. Calcite (but no dolomite), } \\
\text { pyrite, gypsum, and anhydrite are present, also relatively large amounts of sphene and some epidote and possibly some natrolite. }\end{array}$ \\
\hline B) 160 to $\sim 175$ & $\begin{array}{l}\text { Except for the absence of detrital clay minerals and hydrothermal } \mathrm{K} \text {-feldspar, the mineral assemblage is similar to Subzone A. } \\
\text { Amounts of recrystallized quartz and albitized plagioclase increase. }\end{array}$ \\
\hline C) 175 to $\sim 185$ & $\begin{array}{l}\text { Generally similar to Subzone B. The main differences are in the amount of chlorite, which has become an abundant phase, and in } \\
\text { the formation of much pyrrhotite, which coexists with pyrite. }\end{array}$ \\
\hline D) 185 to 267 & $\begin{array}{l}\text { Greenschist facies rocks with the following mineral assemblage: quartz-albite-chlorite-epidote with pyrite and some pyrrhotite. } \\
\text { There is general increase in the amount of epidote with depth. }\end{array}$ \\
\hline
\end{tabular}

Table 2. Mineral zones in sediments at Site 481 .

\section{Sub-bottom}

Depth $(\mathrm{m})$

0 to $\sim 130$

\section{Mineral Assemblage}

Turbidites composed of a mixture of detrital minerals quartz, plagioclase, some alkali feldspars and the clay minerals mixed-layer smectite/illite, illite, and chlorite/kaolinite with biogenic opal-A and calcite. Also very small amounts of the diagenetic minerals; pyrite and clinoptilolite (which is already present, although only in trace amounts, at $\sim 2 \mathrm{~m}$ depth). The base of the turbidites contains more feldspars and quartz and less clay minerals and opal-A than the top of the turbidites. A minor subzone at 36-37 meters depth may represent an altered ash layer, with almost no opal-A, much more quartz than feldspars, much chlorite, and traces of detrital clay minerals and of pyrite, but no clinoptilolite and calcite.

130 to $\sim 171$ Thermally altered zone at upper contact with first sill complex. Average detrital plagioclase and quartz similar to zone above. Between about 130 and 140 meters depth the amount of opal-A decreases rapidly; below 140 meters, there is no opal-A, and the amount of quartz increases. Clinoptilolite disappears at approximately the same depth as opal-A. From about 150 meters depth to the contact with the sill, mainly quartz and feldspar and the following well-crystallized clay minerals are found: up to $\sim 169$ meters, smectite and illite, the absolute and relative abundances of which vary; from 169 meters to contact with sill, primarily illite and chlorite with only traces of smectite; at about 170 meters, analcime and siderite appear. Calcite is present throughout, except at the immediate contact with the sill. Pyrite and gypsum are also present.

171 to $198 \quad$ First sill complex.

198 to $\sim 210$ Thermally altered zone at lower contact with first sill complex. Mainly quartz and feldspar. No opal-A. Traces of the detrital clay minerals illite and chlorite/kaolinite, but the main clay mineral is smectite. Some pyrite, no calcite or clinoptilolite.

210 to $\sim 328$ Some turbidites and thick mass flows. A similar mixture of the detrital, biogenic, and diagenetic minerals described in the zone between 0 and $\sim 130$ meters. Below 270 meters depth, opal-A is however, less abundant. Between approximately 240 and 290 meters, there is a subzone with incidental siderite. Siderite and pyrite do not coexist.

Second, thin, sill complex.

328 to 334

334 to $\sim 351$ Thermally altered zone between second and third sill complexes. Some plagioclase, much quartz-a mixture of detrital and newly formed. Opal-CT coexists with quartz but no opal-A. Well-crystallized smectite and only traces of detrital illite. Analcime instead of clinoptilolite. No calcite.

351 to 364 Third sill complex. 
Table 3. Mineral zones in sediments at Site 478.

\begin{tabular}{|c|c|}
\hline $\begin{array}{l}\text { Sub-bottom } \\
\text { Depth }(\mathrm{m})\end{array}$ & Mineral Assemblage \\
\hline 0 to $\sim 185$ & $\begin{array}{l}\text { Primarily a mixture of the detrital minerals quartz, plagioclase, some alkali feldspars and the clay minerals mixed-layer smectite/ } \\
\text { illite, illite, and chlorite/kaolinite, with the biogenic minerals opal-A and calcite. Also very small amounts of the diagenetic } \\
\text { minerals pyrite, clinoptilolite (first appearance at } \sim 2.5 \mathrm{~m} \text { depth), and protodolomite (first appearance at } \sim 125 \mathrm{~m} \text { depth). }\end{array}$ \\
\hline 185 to $\sim 215$ & $\begin{array}{l}\text { Thermally altered zone at upper contact with first sill complex. Average detrital quartz and plagioclase same as in above zone. } \\
\text { The amount of detrital clay minerals decreases drastically toward the sill; in the last } 4 \text { to } 5 \text { meters, there are only traces of clay } \\
\text { minerals. Although opal-A shows a similar trend, the amount of quartz does not increase significantly with depth. Clinoptilolite } \\
\text { becomes abundant close to contact with the sill and dolomite is a major phase from } \sim 138 \text { meters to the contact; dolomite and } \\
\text { calcite do not coexist. Gypsum and pyrite are present throughout this zone. }\end{array}$ \\
\hline 215 to -240 & First sill complex. \\
\hline 240 to -247 & $\begin{array}{l}\text { Thermally altered zone at lower contact with first sill complex. No significant changes in detrital quartz and plagioclase. Detrital } \\
\text { clay minerals and opal-A are somewhat more abundant at this contact than at upper contact. Some smectite formed, most prob- } \\
\text { ably during the thermal event. Calcite occurs throughout this zone; only some protodolomite and calcite at } \sim 246 \text { meters. Clino- } \\
\text { ptilolite, gypsum, and pyrite are present as well. }\end{array}$ \\
\hline 247 to -250 & $\begin{array}{l}\text { A thin zone with a similar mixture of the detrital, biogenic, and diagenetic minerals as in the uppermost zone between } 0 \text { and } 185 \\
\text { meters. }\end{array}$ \\
\hline 250 to $\sim 253$ & $\begin{array}{l}\text { Thermally altered zone at upper contact with second rather thin sill complex. No change in average detrital quartz and plagio- } \\
\text { clase. The origin of some alkali feldspar is unclear-is it detrital or hydrothermal? Clay minerals consist of very small amounts } \\
\text { of detrital illite, but mainly newly formed, well-crystallized smectite. The amount of opal-A decreases rapidly; at } 252.5 \text { meters } \\
\text { only traces of opal-A are present and the major silica mineral is opal-CT. At } \sim 253 \text { meters opal-A is not present. Opal-CT is the } \\
\text { dominant silica mineral. Its abundance decreases significantly at } 253 \text { meters and quartz becomes the dominant silica mineral. At } \\
\text { lease } 50 \% \text { of the quartz present is newly formed. Calcite is present throughout except at the immediate contact with the sill (no } \\
\text { dolomite). Clinoptilolite is absent from } 252.5 \text { meters to contact with sill and the appearance of analcime. Pyrite is abundant } \\
\text { throughout the zone, and some gypsum is also present. }\end{array}$ \\
\hline 253 to 256.5 & Second, thin, sill complex. \\
\hline 256.5 to $\sim 259$ & $\begin{array}{l}\text { Thermally altered zone at lower contact with second sill complex. No change in average detrital quartz and plagioclase. Small } \\
\text { amounts of detrital clay minerals. Only traces of opal-A but much opal-CT. Except for the immediate contact with the sill calcite } \\
\text { is present throughout, possibly also some dolomite or protodolomite. There is much clinoptilolite at the contact. Pyrite is rather } \\
\text { abundant; only traces of gypsum. }\end{array}$ \\
\hline 259 to $\sim 290$ & $\begin{array}{l}\text { Return to a similar mixture of the detrital, biogenic, and diagenetic minerals described in the zone between } 0 \text { to } 185 \text { meters. On } \\
\text { the average, however, less opal-A. }\end{array}$ \\
\hline 290 to 339 & Thermally altered zone at upper contact with a very thick sill complex. There are three subzones: \\
\hline A) 290 to $\sim 325$ & $\begin{array}{l}\text { The distal band of the thermally altered zone. No change in average detrital quartz, plagioclase, and clay minerals. Opal-A, } \\
\text { however, is present only in trace amounts. The abundance of protodolomite increases; it coexists with calcite, except that at } \\
\sim 303 \text { meters there is a dolostone layer. Clinoptilolite is absent. Some pyrite and gypsum throughout the zone. }\end{array}$ \\
\hline B) 325 to $\sim 337$ & $\begin{array}{l}\text { The intermediate band. Not much change in the detrital quartz and plagioclase, and only very small amounts of detrital clay } \\
\text { minerals. Opal-A is no longer present; instead, opal-CT is as abundant as quartz. Calcite is present throughout, but there is no } \\
\text { dolomite or clinoptilolite. Some pyrite and gypsum throughout. }\end{array}$ \\
\hline C) 337 to $\sim 339$ & $\begin{array}{l}\text { The immediate upper contact with the thick sill complex. Mainly quartz-a mixture of detrital and newly formed-and less } \\
\text { plagioclase. No opal-A, opal-CT, or clinoptilolite. Well-crystallized, newly formed smectite and recrystallized illite between } 338 \\
\text { and } 338.8 \text { meters; below, only much well-crystallized smectite. Calcite is present, but only until the last } 0.5 \text { to } 0.75 \text { meters from } \\
\text { the contact with the sill. Dolomite and clinoptilolite are absent. Pyrite is abundant between } 337 \text { and } 338 \text { meters and less so } \\
\text { below. Gypsum is present throughout. }\end{array}$ \\
\hline 339 to $\sim 464$ & Thick sill complex. \\
\hline
\end{tabular}

$\delta{ }^{18} \mathrm{O}$ values of the thermally altered sediments cluster around approximately $10 \%$, and below the sills between 12 and $13 \%$. At Site 477 , between 120 and $\sim 170$ meters depth, the $\delta 18 \mathrm{O}$ values of the sediments rapidly decrease below the lowest value of $\sim 10 \%$, observed at sill contacts, to igneous values. The $\delta 18 \mathrm{O}$ values of the greenschist facies rocks, between 170 and 230 meters depth, are 6.6 to $7 \%$. Table 5 summarizes these general trends in the $\delta^{18} \mathrm{O}$ values.

Oxygen isotopes of pore fluids at Sites 477,481 , and 478 are given in Table 6, and values for Sites 477 and 481 are shown in Figures 1 and 2.

At each of the sites, the $\delta^{18} \mathrm{O}$ values increase both above and below the sills. Above the shallowest sills, the maximum $\delta^{18} \mathrm{O}$ values observed range between +0.5 and $0.6 \%$ (SMOW). At Site 477 , below the sill, the $\delta^{18} \mathrm{O}$ values of the pore fluids associated with the greenschist facies rocks range between +0.8 and $1.4 \%$. At Site 481 , between the first and second sills, a maximum $\delta^{18} \mathrm{O}$ value of $+1.97 \%_{0} \pm 0.05$ was measured. At Site 478 , the $\delta^{18} \mathrm{O}$ values of the pore fluids between the first and second sill, but also between the second sill and the thick third sill, are similar and relatively low, about 0.3 to $0.4 \%$.

It is necessary to explain the observations that (a) the $\delta^{18} \mathrm{O}$ values of pore fluids associated with thermally altered sediments, by the most massive sill complex encountered (Site 478), are lower than those associated with thermally altered sediments by sill complexes of average thickness, and (b) that the $\delta^{18} \mathrm{O}$ values of the pore fluids of sediments thermally altered by sill intrusions only (e.g., as at Site 481) are more positive, relative to SMOW, than the pore fluids recovered from the greenschist facies rocks in the active and intensive hydrothermal system at Site 477.

To determine temperatures of formation, recrystallized calcites at the contact with the first sill in Hole $481 \mathrm{~A}$ and separated quartz and chlorite from the greenschist facies rocks at Site 477 were also analyzed for their $\delta^{18} \mathrm{O}$ values.

\section{TWO TYPES OF HYDROTHERMAL SYSTEMS}

On the basis of the detailed mineralogical and oxygen isotopic analyses, two distinct hydrothermal systems are 
Table 4. Isotopic composition of bulk sediments, Guaymas Basin.

\begin{tabular}{|c|c|c|c|}
\hline $\begin{array}{l}\text { Sample } \\
\text { (interval in } \mathrm{cm} \text { ) }\end{array}$ & $\begin{array}{l}\text { Sub-bottom } \\
\text { Depth }(m)\end{array}$ & $\begin{array}{l}{ }^{18} \mathrm{O}(\%) \\
\text { SMOW }\end{array}$ & Description \\
\hline \multicolumn{4}{|l|}{ Hole 477} \\
\hline $2-2,84-86$ & 3.3 & 18.69 & Intraturbidite \\
\hline $3-1,140-150$ & 11.9 & 14.50 & Base of turbidite \\
\hline $4-1,51-53$ & 20.5 & 23.35 & Top of turbidite \\
\hline $5-1,140-150$ & 30.9 & 19.43 & Intraturbidite \\
\hline $7-1,140-150$ & 49.9 & 15.06 & $\begin{array}{l}\text { Recrystallized sediment, } \sim 10 \mathrm{~m} \\
\text { above sill }\end{array}$ \\
\hline $7-2,35-37$ & 50.4 & 10.02 & $\begin{array}{l}\text { Recrystallized sediment close to } \\
\text { upper contact with sill }\end{array}$ \\
\hline $12-4,134-135$ & 92.3 & 5.45 & Dolerite sill \\
\hline $15-1,126-131$ & 106.3 & 12.07 & $\begin{array}{l}\text { Recrystallized sediment close to lower } \\
\text { contact with sill }\end{array}$ \\
\hline $16-1,10-11$ & 115.1 & 14.20 & $\begin{array}{l}\text { Partially recrystallized sediment } \\
\sim 15 \mathrm{~m} \text { below sill }\end{array}$ \\
\hline $16-4,140-150$ & 120.9 & 10.26 & $\begin{array}{l}\text { Hydrothermally recrystallized sed- } \\
\text { iment }\end{array}$ \\
\hline $17-2,140-150$ & 127.4 & 9.64 & $\begin{array}{l}\text { Hydrothermally recrystallized sed- } \\
\text { iment }\end{array}$ \\
\hline $19-1,140-150$ & 144.9 & 9.17 & $\begin{array}{l}\text { Hydrothermally recrystallized sed- } \\
\text { iment }\end{array}$ \\
\hline $20-1,140-150$ & 154.4 & 8.11 & Greenschist facies rocks \\
\hline $22-1,140-150$ & 173.4 & 7.16 & Greenschist facies rocks \\
\hline $23-0, \mathrm{CC}$ & 181.5 & 6.75 & Greenschist facies rocks \\
\hline $23-1, \quad 34-36$ & 181.8 & 6.59 & Greenschist facies rocks \\
\hline \multicolumn{4}{|l|}{ Hole 477A } \\
\hline $9-1,84-86$ & 229.8 & 6.76 & Greenschist facies rocks \\
\hline \multicolumn{4}{|l|}{ Hole 481} \\
\hline $2-1,145-150$ & 6.2 & 24.48 & Top of turbidite \\
\hline $4-1,23-25$ & 14.5 & 22.09 & Intraturbidite \\
\hline $9-1,145-150$ & 39.5 & 15.99 & Base of turbidite \\
\hline \multicolumn{4}{|l|}{ Hole $481 \mathrm{~A}$} \\
\hline $3-1,101-103$ & 62.0 & 18.89 & Intraturbidite \\
\hline $4-2,140-150$ & 73.4 & 21.96 & Intraturbidite \\
\hline $6-7,7-9$ & 98.6 & 27.00 & Top of turbidite \\
\hline $9-6,56-58$ & 126.1 & 24.20 & Intraturbidite \\
\hline $10-4,82-84$ & 132.8 & 16.55 & Base of turbidite \\
\hline $11-2,144-146$ & 139.9 & 18.47 & $\begin{array}{l}\text { Partially recrystallized sediment } \\
\sim 30 \mathrm{~m} \text { above sill }\end{array}$ \\
\hline $12-4,38-40$ & 151.4 & 13.80 & $\begin{array}{l}\text { Recrystallized sediment } \sim 18 \mathrm{~m} \\
\text { above sill }(\sim 30 \mathrm{~m} \text { thick })\end{array}$ \\
\hline $13-1,114-116$ & 157.2 & 12.27 & $\begin{array}{l}\text { Recrystallized sediment }-12 \mathrm{~m} \\
\text { above sill }\end{array}$ \\
\hline $14-2,99-101$ & 168.0 & 9.89 & $\begin{array}{l}\text { Recrystallized sediment close to } \\
\text { upper contact with sill }\end{array}$ \\
\hline $14-3,47-49$ & 169.0 & 10.14 & $\begin{array}{l}\text { Recrystallized sediment at upper } \\
\text { contact with sill }\end{array}$ \\
\hline $14-3,140-150$ & 169.9 & 10.12 & $\begin{array}{l}\text { Recrystallized sediment at upper } \\
\text { contact with sill }\end{array}$ \\
\hline $18-1,14-18$ & 203.6 & 13.04 & $\begin{array}{l}\text { Recrystallized sediment close to } \\
\text { lower contact with sill }\end{array}$ \\
\hline $18-1,32-35$ & 203.8 & 12.22 & $\begin{array}{l}\text { Recrystallized sediment close to } \\
\text { lower contact with sill }\end{array}$ \\
\hline $20-1,99-101$ & 223.5 & 19.36 & Intraturbidite \\
\hline $22-5,92-94$ & 248.4 & 17.11 & Mass flow \\
\hline $26-6,140-150$ & 288.5 & 17.41 & Mass flow \\
\hline $28-5,140-150$ & 306.0 & 16.43 & Mass flow \\
\hline $30-4,64-66$ & 322.7 & 16.72 & $\begin{array}{l}\text { Mass flow, } \sim 6 \mathrm{~m} \text { above thin sill } \\
(\sim 5 \mathrm{~m} \text { thick })\end{array}$ \\
\hline $33-1,29-31$ & 346.3 & 10.36 & $\begin{array}{l}\text { Recrystallized sediment between two } \\
\text { adjacent sills }(\sim 17 \mathrm{~m} \text { apart })\end{array}$ \\
\hline \multicolumn{4}{|l|}{ Hole 478} \\
\hline $29-2,140-150$ & 253.5 & 16.95 & $\begin{array}{l}\text { Slightly recrystallized sediment at } \\
\text { contact with thin sill }(-5 \mathrm{~m} \\
\text { thick) }\end{array}$ \\
\hline
\end{tabular}

recognized in the Guaymas Basin. The first and minor system is driven by the intrusions of hot sills into highly porous, cold, hemipelagic sediments, relatively rich in organic matter, as described by Einsele et al. (1980). The second and major system is driven by relatively shallow magma chambers, as in the ridge crest systems, such as the Red Sea, EPR $21^{\circ} \mathrm{N}$, and the Galapagos spreading center (Degens and Ross, 1969; Corliss et al., 1979; Edmond et al., 1979; Spiess et al., 1980). The difference

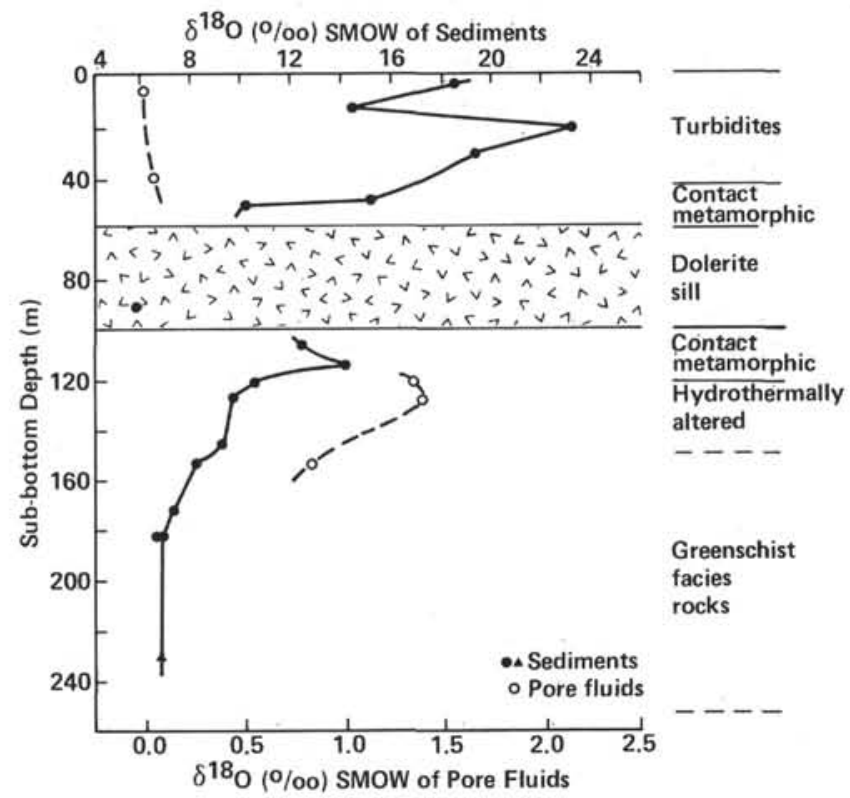

Figure 1. Oxygen isotope data for unaltered and thermally altered sediments and pore fluids versus depth, DSDP Site 477.

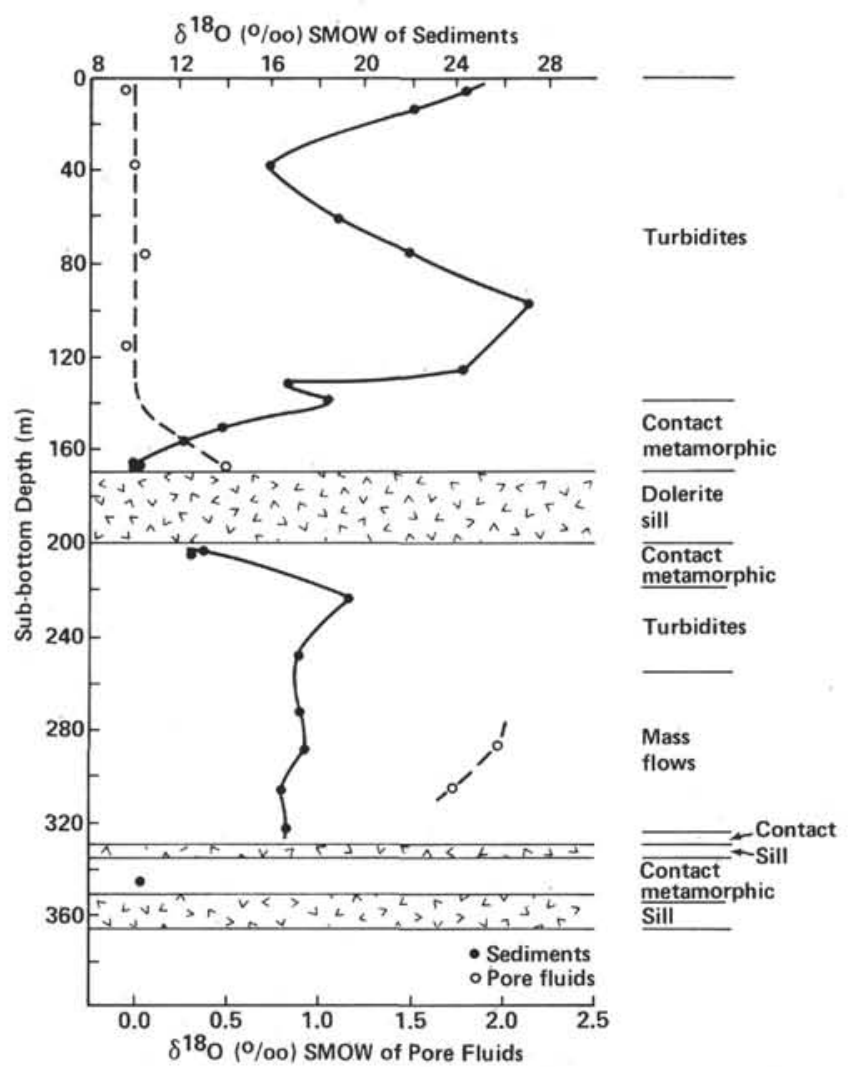

Figure 2. Oxygen isotope data for unaltered and thermally altered sediments and pore fluids versus depth, DSDP Site 481.

between these systems and the Guaymas Basin is the near absence of sediments at the ridge crest and the rapid and massive accumulation of sediments in the Guaymas Basin. The chemistry of the hydrothermal 
fluids, therefore, reflects their interaction with both basalt and sediments (Gieskes et al., this volume, Pt. 2), and the chemistry and mineralogy of the thermally recrystallized sediments are controlled by the temperature and chemistry of the hydrothermal fluids.

On the basis of the mineralogical zones of the three DSDP sites in the Guaymas Basin, described in Tables 1,2 , and 3 and the $\delta^{18} \mathrm{O}$ data of Tables 4 and 6 , the following most important mineralogical and oxygen isotopic differences in the thermally recrystallized sediments of the two suggested hydrothermal systems are:

\begin{tabular}{|c|c|}
\hline $\begin{array}{l}\text { Hydrothermal System } \\
\text { Driven by Sill Intrusions }\end{array}$ & $\begin{array}{c}\text { Hydrothermal System } \\
\text { Driven by Shallow Magma } \\
\text { Chamber }\end{array}$ \\
\hline $\begin{array}{l}\text { 1. Thickness of thermally altered } \\
\text { zone extends from } 3 \text { to a } \\
\text { maximum of } 50 \text { meters; on } \\
\text { the average it is } 20 \text { to } 30 \text { me- } \\
\text { ters thick. }\end{array}$ & $\begin{array}{l}\text { Thickness of thermally altered } \\
\text { zone is greater than } 140 \text { meters. }\end{array}$ \\
\hline $\begin{array}{l}\text { 2. Smectite is the most impor- } \\
\text { tant and generally the only } \\
\text { hydrothermal sheet-silicate. } \\
\text { Illite is present but uncom- } \\
\text { mon (Site } 481 \text { above the first } \\
\text { sill; Site } 478 \text { above the thick } \\
\text { sill). Chlorite is rare and co- } \\
\text { exists with illite (only at Site } \\
481 \text { above the first sill). }\end{array}$ & $\begin{array}{l}\text { Chlorite is the only and domi- } \\
\text { nant hydrothermal sheet-silicate. }\end{array}$ \\
\hline $\begin{array}{l}\text { 3. Analcime is the main Na-sili- } \\
\text { cate. Clinoptilolite is rare. } \\
\text { Detrital plagioclase is not } \\
\text { albitized. }\end{array}$ & $\begin{array}{l}\text { Albite is abundant and is the } \\
\text { main Na-silicate. Analcime and } \\
\text { clinoptilolite are not present. } \\
\text { Detrital plagioclase is albitized. }\end{array}$ \\
\hline $\begin{array}{l}\text { 4. No opal-A and mainly small } \\
\text { to moderate amounts of hy- } \\
\text { drothermal quartz, which co- } \\
\text { exists with detrital quartz. } \\
\text { Opal-CT is present but un- } \\
\text { common. }\end{array}$ & $\begin{array}{l}\text { No opal-A or opal-CT, only } \\
\text { much hydrothermal quartz, with } \\
\text { no or only small amounts of } \\
\text { detrital quartz. }\end{array}$ \\
\hline $\begin{array}{l}\text { 5. Epidote, sphene, or pyrrho- } \\
\text { tite are absent. }\end{array}$ & $\begin{array}{l}\text { Epidote, sphene, and pyrrhotite } \\
\text { are present. }\end{array}$ \\
\hline $\begin{array}{l}\text { 6. Except at the immediate con- } \\
\text { tact with the sills, calcite and } \\
\text { occasionally dolomite are } \\
\text { present. }\end{array}$ & Calcite or dolomite are absent. \\
\hline 7. Pyrite is present. & Pyrite may be abundant. \\
\hline $\begin{array}{l}\text { 8. The } \delta^{18} \mathrm{O} \text { values of the hy- } \\
\text { drothermal sediments range } \\
\text { between } 9.9 \text { and } 13 \% \\
\text { (SMOW). }\end{array}$ & $\begin{array}{l}\text { The } \delta^{18} \mathrm{O} \text { value of the hydrother- } \\
\text { mal sediments range between } 6.6 \\
\text { and } 10.3 \% \text { (SMOW). }\end{array}$ \\
\hline $\begin{array}{l}\text { 9. The } \delta^{18} \mathrm{O} \text { values of the pore } \\
\text { fluids range between } \\
+0.28 \text { and } 1.97 \% \\
\text { (SMOW). }\end{array}$ & $\begin{array}{l}\text { The } \delta^{18} \mathrm{O} \text { values of the pore } \\
\text { fluids range between } \\
+0.83 \text { and } 1.34 \% \\
\text { (SMOW). }\end{array}$ \\
\hline
\end{tabular}

Diagenetic pyrite is also present and occurs as framboidal pyrite. The hydrothermal crystals are either cubic or pyritohedral.

Hydrothermal K-feldspar was observed only at the lower contact with the sill at Site 477. Its formation, however, is prompted by the second hydrothermal system below the sill. The high-temperature fluids, heated to temperatures $>300^{\circ} \mathrm{C}$, leached $\mathrm{K}^{+}$from the basalt and the sediments below (see Niemitz, this volume, Pt. 2; Gieskes et al., this volume, Pt. 2). The sill complex
Table 5. Summary of $\delta^{18} \mathrm{O}$ variations of sediments and pore fluids, Sites 481 and 477 .

\begin{tabular}{|c|c|c|}
\hline \multirow[b]{2}{*}{ Sample Description } & \multicolumn{2}{|c|}{$\delta^{18} \mathrm{O}(\%)$ SMOW of } \\
\hline & Solids & Pore Fluids \\
\hline \multicolumn{3}{|l|}{ Site 481} \\
\hline $\begin{array}{l}\text { Top of turbidites } \\
\text { Base of turbidites } \\
\text { Recrystallized sediments above sills } \\
\text { Recrystallized sediments below sills }\end{array}$ & $\begin{array}{r}24.5 \text { to } 27.0 \\
16.0 \text { to } 16.6 \\
9.9 \text { to } 10.4 \\
12.2 \text { to } 13.0\end{array}$ & $\begin{array}{l}0.02 \text { to } 0.08 \\
0.53 \\
1.69 \text { to } 1.97\end{array}$ \\
\hline \multicolumn{3}{|l|}{ Site 477} \\
\hline $\begin{array}{l}\text { Top of turbidites } \\
\text { Base of turbidites } \\
\text { Recrystallized sediment above sill } \\
\text { Recrystallized sediment below sill } \\
\text { Greenschist facies rocks }\end{array}$ & $\begin{array}{l}23.5 \\
14.5 \text { to } 16.5 \\
10.0 \\
12.1 \\
6.6 \text { to } 7.2\end{array}$ & 0.01 to 0.06 \\
\hline
\end{tabular}

Table 6. Isotopic composition of pore fluids, Guaymas Basin, Sites 477, 481, and 478.

\begin{tabular}{lrr}
\hline $\begin{array}{c}\text { Sample } \\
\text { (interval in cm) }\end{array}$ & $\begin{array}{c}\text { Sub-bottom } \\
\text { Depth (m) }\end{array}$ & $\begin{array}{r}\delta^{18} \mathrm{O}\left(\%_{0}\right) \\
\text { SMOW }\end{array}$ \\
\hline Hole 477 & & \\
& & \\
$2-3,140-150$ & 5.4 & 0.01 \\
$5-1,140-150$ & 30.9 & 0.06 \\
$16-4,140-150$ & 120.9 & 1.34 \\
$17-2,140-150$ & 127.4 & 1.38 \\
$20-1,140-150$ & 154.4 & 0.83 \\
Hole 481 & & \\
& & \\
$2-1,140-150$ & 6.2 & -0.02 \\
$9-1,140-150$ & 39.5 & 0.00 \\
& & \\
Hole 481A & & \\
$4-2,140-150$ & 73.4 & 0.08 \\
$8-5,140-150$ & 115.9 & -0.05 \\
$14-3,140-150$ & 169.9 & 0.53 \\
$26-6,140-150$ & 288.5 & 1.97 \\
$28-5,140-150$ & 306.0 & 1.69 \\
& & \\
Hole 478 & & \\
& & \\
$2-4,140-150$ & 9.5 & 0.10 \\
$7-5,140-150$ & 58.5 & 0.11 \\
$17-3,140-150$ & 150.5 & 0.56 \\
$19-5,140-150$ & 167.0 & 0.38 \\
$29-2,140-150$ & 253.5 & 0.33 \\
$33-1,140-150$ & 280.5 & 0.28 \\
\hline & & \\
\hline
\end{tabular}

acts as a barrier for the upwelling $\mathrm{K}^{+}$-rich hydrothermal solutions and $\mathrm{K}$-feldspar precipitates.

The transformation of opal-A directly to quartz occurred at the thermally altered zones above the sills and in the major hydrothermal system at Site 477 . The observation that the thermally affected zones are much thicker above than below the sills indicates an upward movement of the hydrothermal solutions. The solubilities of all silica phases increase and approach each other with temperature (e.g., Kennedy, 1950; Alexander et al., 1954; Siever, 1962; Fournier, 1973). The rates of transformation of opal-A to opal-CT and opal-CT to 
quartz also increase with increasing temperatures (e.g., Ernst and Calvert, 1969; Mizutani, 1977; Kastner et al., 1977; Kastner, 1981).

When a hot basalt sill intrudes into sediments rich in opal-A (mainly diatoms), all the opal-A dissolves, as indicated in Tables 1, 2, 3 and Appendix A, and shown in Figure 3. Much of the dissolved silica is carried away by the rapidly uprising hydrothermal solutions. The remaining dissolved silica concentrations most probably are within the stability field of quartz, between $150^{\circ}$ and $200^{\circ} \mathrm{C}$, and therefore do not form opal-CT. The absence of opal-CT in the major hydrothermal system below the sill at Site 477 is attributed to two factors: (a) the higher temperatures of this hydrothermal system and consequent higher solubility values of quartz, and (b) the fast rate at which opal-CT transforms to quartz at approximately $300^{\circ} \mathrm{C}$, and the relatively long period of time over which this particular hydrothermal system has been active.

Opal-CT forms only between adjacent sills where the hydrothermal fluids are "trapped" or in association with sills which intrude the sediments at greater depth, where the rising, silica-rich, hydrothermal solutions do not exit the sediment column. The opal-CT will form a few tens of meters above the contact with the sill, as, for example, at Site 478.

On the basis of the hydrothermal mineralogy of the sediments and $\delta^{18} \mathrm{O}$ values of recrystallized calcite close to the sill contacts, it is concluded that temperatures of about $150^{\circ}$ to $200^{\circ} \mathrm{C}$ prevailed at the sill contacts. Occasionally they were slightly higher, but did not exceed $230^{\circ}$ to $250^{\circ} \mathrm{C}$. (The hydrothermal minerals within the sills, which are not discussed in this chapter, indicate higher temperatures of formation, and thus steep ther-

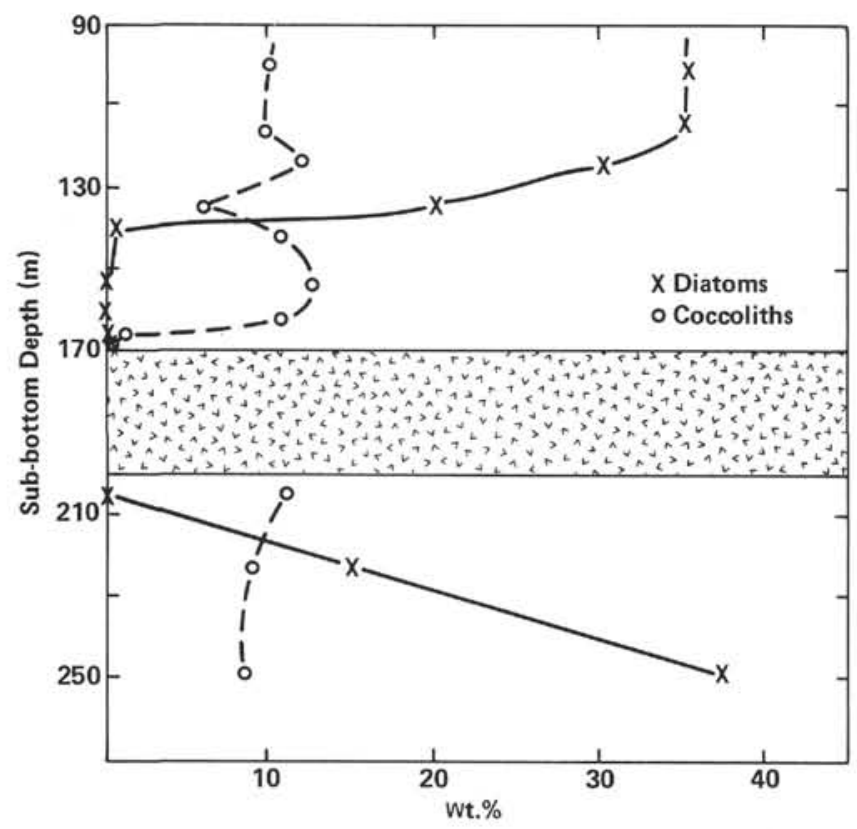

Figure 3. Distribution of diatoms and coccoliths above and below the shallowest sill of Site 481 . mal gradients between the sills and sediments.) The main evidence for tinis temperature range is as follows:

a) Clinoptilolite disappears and analcime forms instead. Opal-A is present in the clinoptilolite and quartz in the analcime zone. The following reaction is suggested:

Clinoptilolite + Opal-A $+\mathrm{Na}^{+}-$Analcime + Quartz $+\mathrm{K}^{+}+\mathrm{H}_{2} \mathrm{O}$

Experimental work on the reaction analcime + quartz $=$ albite $+\mathrm{H}_{2} \mathrm{O}$ as a function of temperature and pressure (Thompson, 1971) indicates temperatures of $170^{\circ}$ to $200^{\circ} \mathrm{C}$ for analcime stability in the Guaymas Basin regime. No hydrothermal albite was observed at sill contacts. It is, however, a major phase in the greenschist facies rocks at Site 477.

b) The oxygen isotopes of recrystallized calcite 1 to 2 meters above the first sill at Site 481 indicate temperatures of formation of $130^{\circ}$ to $170^{\circ} \mathrm{C}$, as shown in Table 7. Calcite, however, was not observed at the immediate contact with the sills.

c) Similar mineralogical zones were described from the Cerro Prieto hydrothermal system and were related to temperature zones (e.g., Hoagland and Elders, 1978; Olson and Elders, 1978; Elders et al., 1979). Formation of smectite was observed up to $150^{\circ} \mathrm{C}$, and also formation of the assemblage illite-chlorite, usually between $150^{\circ}$ and $180^{\circ} \mathrm{C}$, but also up to $230-250^{\circ} \mathrm{C}$. As in the Guaymas Basin, dolomite was observed to disappear in this zone at $\sim 180^{\circ} \mathrm{C}$. At a higher temperature, > $\sim 230^{\circ} \mathrm{C}$, a zone of chlorite with or without calc-silicates was observed in the Cerro Prieto system, but not at sill contacts in the Guaymas Basin.

On the basis of the above temperatures of formation, the $\delta^{18} \mathrm{O}$ value of the thermally altered sediments and of their pore fluids provides information about the water/ rock ratio of this hydrothermal system. Assuming a closed system, the calculated water/rock wt. \% ratios are between $1.5 / 1$ and $3 / 1$. The thickness of the thermally altered zone is relatively small. Accordingly, in the Guaymas Basin, where the sediments have a $70-80 \%$ porosity and are highly hydrous, recharge of fluids is not necessary, and a closed-system assumption is thus indicated.

On the basis of the hydrothermal mineralogy of the sediments in the greenschist facies rocks and their $\delta^{18} \mathrm{O}$ values, it is concluded that temperatures of $300^{\circ} \pm 50^{\circ} \mathrm{C}$

Table 7. Isotopic composition of recrystallized calcite at contact with sill, Hole 481A.

\begin{tabular}{|c|c|c|c|c|c|c|}
\hline \multirow{2}{*}{$\begin{array}{c}\text { Core/Section } \\
\text { (interval in } \mathrm{cm} \text { ) }\end{array}$} & \multirow{2}{*}{$\begin{array}{l}\text { Sub-bottom } \\
\text { Depth (m) }\end{array}$} & \multirow{2}{*}{$\begin{array}{c}{ }^{\delta^{13}} \mathrm{C}\left(\%_{0}\right) \\
\mathrm{PDB}^{\mathrm{a}}\end{array}$} & \multicolumn{2}{|c|}{$\delta^{18} \mathrm{O}\left(\%_{0}\right)$} & \multirow[b]{2}{*}{$\mathrm{T}\left({ }^{\circ} \mathrm{C}\right)^{\mathrm{b}}$} & \multirow[b]{2}{*}{$\mathrm{T}\left({ }^{\circ} \mathrm{C}\right)$} \\
\hline & & & PDB & $\overline{\text { SMOW }}$ & & \\
\hline $14-3,122-124$ & 169.7 & -4.44 & -16.77 & 13.57 & 139 & 145 \\
\hline $14-3,125-127$ & 169.8 & -5.18 & -18.04 & 12.26 & 155 & 163 \\
\hline $14-4,29-31$ & 170.3 & -5.08 & -18.05 & 12.25 & 155 & 163 \\
\hline $14-4,44-47$ & 170.4 & -4.68 & -16.13 & 14.23 & 130 & 136 \\
\hline
\end{tabular}

a Carbonate standard derived from the rostra of Belemnitella americana from the Pee Dee Formation of South Carolina.

b Temperature $(\mathrm{T})$ calculated using the recalculated calcite-water oxygen isotope fractionation of O'Neil et al. (1969), using the $\mathrm{CO}_{2}-\mathrm{H}_{2} \mathrm{O}$ fractionation factor at $25^{\circ} \mathrm{C}$ of O'Neil et al. (1975), and assuming a $\delta^{18} \mathrm{O}_{2} \mathrm{H}_{2} \mathrm{O}=0 \%$ sMOW.

c Assuming $\delta^{18} \mathrm{O}_{2} \mathrm{O}=+0.53 \%$ SMOW. 
are responsible for the formation of these rocks. Hydrothermal quariz and chlorite were separated for oxygen isotope analysis. Figures 4 and 5 show the successful separation of pure chlorite, which is iron-rich. The grain size of the chlorite is about $1 \mu \mathrm{m}$, and Figure 6 shows the coexisting hydrothermal euhedral quartz crystals. On the basis of Wenner and Taylor's (1971) empirical equation for $\Delta$ quartz-chlorite, a temperature of formation of $300 \pm 50^{\circ} \mathrm{C}$ was calculated. This is a temperature range similar to that in the Cerro Prieto hydrothermal field, where chlorite and calc-silicates, such as epidote, occur in the temperature zone between $250^{\circ}$ and $350^{\circ} \mathrm{C}$ (e.g., Hoagland and Elders, 1978; Elders et al., 1979). Oxygen isotope analyses of hydrothermally altered oceanic rocks by Stakes and O'Neil (1982) also indicate temperatures of $\sim 250-350^{\circ} \mathrm{C}$ for epidote-rich greenstones.

Assuming a closed system, the calculated minimum water/rock wt. $\%$ ratio is $12 / 1$, an unrealistically high ratio. Therefore, an open (single-pass) system with continuous recharge is assumed. The calculated water/rock wt. $\%$ ratio in such an open system is approximately $2 / 1$ to $3 / 1$. The calculated water/rock ratio for the EPR $21^{\circ} \mathrm{N}$ hydrothermal system (East Pacific Rise Study Group, 1980) is lower, about unity. The $p \mathrm{H}$ of the major hydrothermal solutions in the Guaymas Basin should be less acidic than the hydrothermal fluids in the EPR $21^{\circ} \mathrm{N}$ system, because of the relatively small amounts of hydration reactions in this system (and possibly also because of the high alkalinities in the pore fluids of the sediments, which are rich in organic matter.

The relatively low positive $\delta^{18} \mathrm{O}$ values of the pore fluids at Site 478 as compared with Site 481 indicate that the 478 system is older than the one at Site 481 . Diffusion has smoothed out the original $\delta^{18} \mathrm{O}$ profile.

\section{CONCLUSIONS}

Mineralogical and oxygen isotope analyses of the sediments and pore fluids at Sites 477,481 , and 478 in the Guaymas Basin indicate that two distinct hydrothermal systems operate in this basin.

The minor system is caused by the intrusion of hot sills into highly porous cold sediments and can be modeled as a closed hydrothermal system at $150-200^{\circ} \mathrm{C}$.

As in the ridge crest hydrothermal systems, the major hydrothermal system in the Guaymas Basin is driven by relatively shallow magma chambers. It cannot be modeled as a closed system. Recharge of fluids at a calculated water/rock ratio of $2 / 1$ to $3 / 1$ is required. The temperature range of this hydrothermal system is 300 $\pm 50^{\circ} \mathrm{C}$. The vertical discharge of the hydrothermal fluids occurs through faults until they encounter sills, which force a horizontal flow toward another fault system.

\section{ACKNOWLEDGMENTS}

The author is grateful to Dr. J. M. Gieskes and to Mr. D. B. Kent for their review of the manuscript and for their constructive comments. I also thank Dr. P. A. Baker for his help in the $\delta^{18} \mathrm{O}$ analyses of several pore fluids. Without the skillful and conscientious laboratory work of Ms. G. Anderson, the acquisition of all the data would have been impossible. This research was supported by NSF Grants OCE78-09652 and OCE80-24630.

\section{REFERENCES}

Alexander, G. B., Heston, W. M., and Iler, R. K., 1954. The solubility of amorphous silica in water. J. Phys. Chem., 58:453-455.

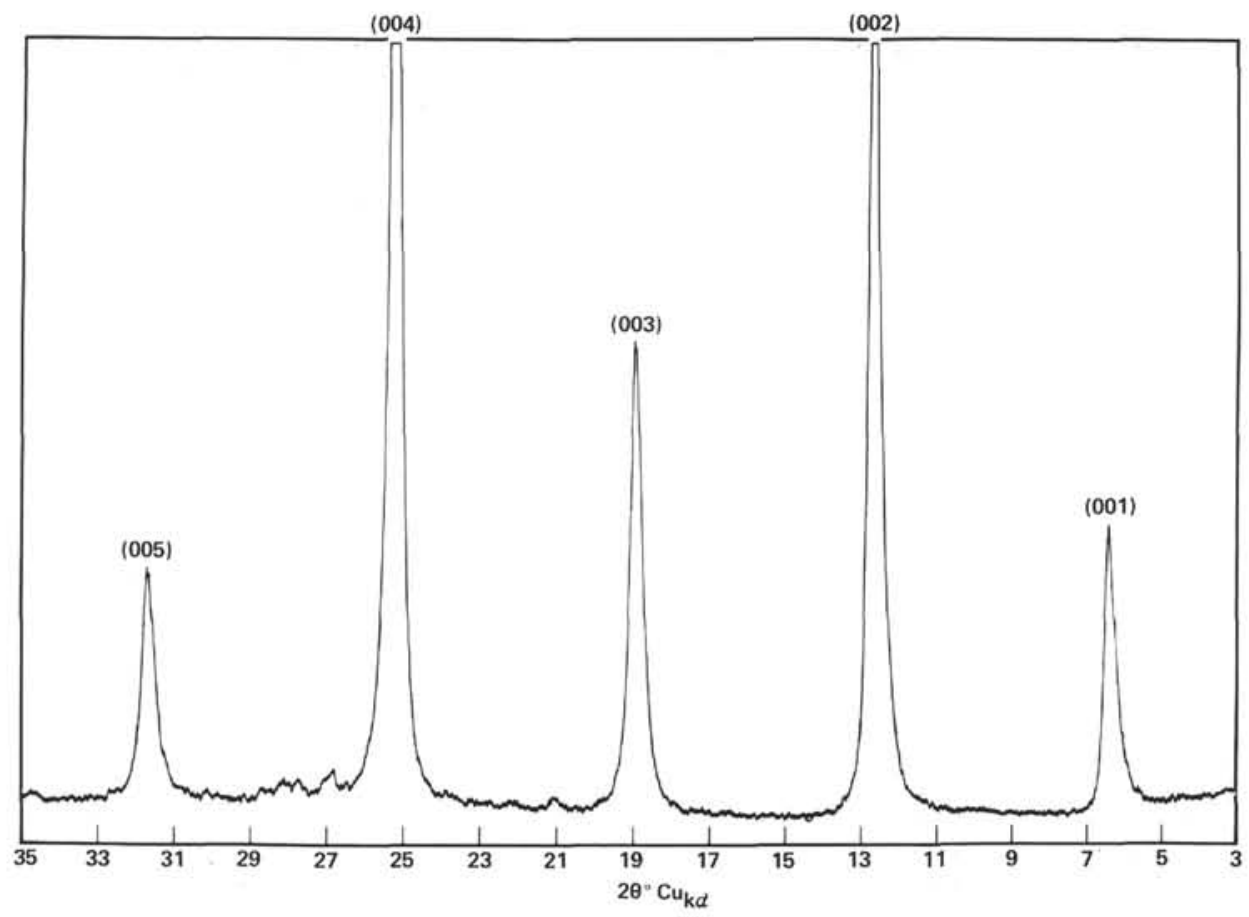

Figure 4. X-ray diffraction pattern of separated chlorite, Sample $477-23-1,34-36 \mathrm{~cm} .2 \theta^{\circ} \mathrm{Cu}_{\mathrm{K} \alpha}, 1^{\circ} / \mathrm{min}$. 
Becker, K., 1981. Heat flow studies of spreading center hydrothermal processes [Ph.D. dissert.]., University of California, San Diego.

Calvert, S. E., 1966. Accumulation of diatomaceous silica in the sediments of the Gulf of California. Geol. Soc. Am. Bull., 77: 569-596.

Clayton, R. N., and Mayeda, T. K., 1963. The use of bromine pentafluoride in the extraction of oxygen from oxides and silicates for isotopic analysis. Geochim. Cosmochim. Acta, 27:43-52.

Corliss, J. B., Dymond, J., Gordon, L. I., Edmond, J. M., Von Heezen, R. P., Ballard, R. D., Green, K., Williams, D., Bainbridge, A., Crane, K., and van Andel, Tj. H., 1979. Submarine thermal springs on the Galapagos Rift. Science, 203:1073-1083.

Craig, H., 1961. Standard for reporting concentrations of deuterium and oxygen-18 in natural waters. Science, 133:1833.

Degens, E. T., and Ross, D. A., 1969. Hot Brines and Recent Heavy Metal Deposits in the Red Sea: New York (Springer-Verlag).

East Pacific Rise Study Group, 1981. Crustal processes of the midocean ridge. Science, 213:31-40.

Edmond, J. M., Measures, C., McDuff, A. E., Chan, L. H., Collier, R., Grant, B., Gordon, L. I., and Corliss, J. B., 1979. Ridge crest hydrothermal activity and the balances of the major and minor elements in the ocean: The Galapagos data. Earth Planet. Sci. Lett., 46:1-18.

Edmond, J. M., Measures, C., Mangum, B., Grant, B., Sclater, F. R., Collier, R., Hudson, A., Gordon, L. I., and Corliss, J. B., 1979. On the formation of metal-rich deposits at ridge crests. Earth Planet. Sci. Lett., 46:19-30.

Einsele, G., Gieskes, J. M., Curray, J., Moore, D. G., Aguayo, E., Aubry, M. P., Fornari, D., Guerrero, J., Kastner, M., Kelts, K., Lyle, M., Matoba, Y., Molina-Cruz, A., Niemitz, J., Rueda, J., Saunders, A., Schrader, H., Simoneit, B., and Vacquier, V., 1980. Intrusion of basaltic sills into highly porous sediments, and resulting hydrothermal activity. Nature, 283:441-445.

Elders, W. A., Hoagland, J. R., McDowell, S. D., and Cobo, J. M., 1979. Hydrothermal mineral zones in the geothermal reservoir of Cerro Prieto. Geothermics, 8:201-209.

Epstein, S. and Mayeda, T., 1953. Variations of $\mathrm{O}^{18}$ content of water from natural sources. Geochim. Cosmochim. Acta, 4:213-224.

Ernst, W. G., and Calvert, S. E., 1969. An experimental study of the recrystallization of porcelanite and its bearing on the origin of some bedded cherts. Am. J. Sci., 267A:114-133.

Fournier, R. O., 1973. Silica in thermal waters: Laboratory and field investigation. Hydrogeochemistry: Proc. Symp. Hydrogeochem. Biogeochem., 1970: Washington (J. W. Clarke), pp. 122-139.

Francheteau, J., Needham, H. D., Choukroune, P., Juteau, T., Seguret, M., Ballard, R. D., Fox, P. J., Normark, W., Carranza, A., Cordoba, D., Guerrero, J., Rangin, C., Bougault, H., Cambon, P., and Hekinian, R., 1979. Massive deep-sea sulphide ore deposits discovered on the East Pacific Rise. Nature, 277:523-528.

Haymon, R. M., and Kastner, M., 1981. Hot spring deposits on the East Pacific Rise at $21^{\circ} \mathrm{N}$ : Preliminary description of mineralogy and genesis. Earth Planet. Sci. Lett., 53:363-381.

Hoagland, J. R., and Elders, W. A., 1978. Hydrothermal mineralogy and isotopic geochemistry in the Cerro Prieto geothermal field, Mexico. I. Hydrothermal mineral zonation. Geotherm. Resourc. Counc. Trans., 2:283-286.

Kastner, M., 1981. Authigenic silicates in deep-sea sediments: formation and diagenesis. In Emiliani, C. (Ed.), The Sea (Vol. 7): New York (Wiley), 915-980.

Kastner, M., and Gieskes, J. M., 1979. Hydrothermal activity at the northern spreading axis of the Guaymas Basin, Gulf of California. Geol. Soc. Am., 92nd Ann. Meet., p. 454. (Abstract)

Kastner, M., Keene, J. B., and Gieskes, J. M., 1977. Diagenesis of siliceous oozes, I. Chemical controls on the rate of opal-A to opalCT transformation-an experimental study. Geochim. Cosmochim. Acta, 41:1041-1059.

Kennedy, G. C., 1950. A portion of the system silica-water. Econ. Geol., 45:629-653.

Lawver, L. A., and Williams, D. L., 1979. Heat flow in the central Gulf of California. J. Geophys. Res., 84:3465-3478.
Lawver, L. A., Williams, D. L., and von Herzen, R. P., 1975. A major geothermal anomaly in the Gulf of California. Nature, 257: 23-28.

Lonsdale, P., 1978. Submersible exploration of Guaymas Basin: A preliminary report of the Gulf of California 1977 operations of DSV-4 "Seacliff." SIO Ref. 78-1.

Lonsdale, P., Bischoff, J. L., Burns, V. M., Kastner, M., and Sweeney, R. E., 1980. A high-temperature hydrothermal deposit on the seabed at a Gulf of California spreading center. Earth Planet. Sci. Lett., 49:8-20.

Lupton, J. E., 1979. Helium-3 in the Guaymas Basin: Evidence for injection of mantle volatiles in the Gulf of California. J. Geophys. Res., 84:7446-7452.

McCrea, J. M., 1950. On the isotopic chemistry of carbonates and a paleotemperature scale. J. Chem. Phys., 18:849-857.

Mizutani, S., 1977. Progressive ordering of cristobalitic silica in the early stages of diagenesis. Contrib. Mineral. Petrol., 61:129-140.

Moore, D. G., 1973. Plate-edge deformation and crustal growth, Gulf of California structural province. Geol. Soc. Am. Bull., 84: 1883-1906.

Muehlenbachs, K., and Clayton, R. N., 1976. Oxygen isotope composition of the oceanic crust and its bearing on seawater. J. Geophys. Res., 81:4365-4369.

Olson, E. R., and Elders, W. A., 1978. Hydrothermal mineralogy and isotopic geochemistry in the Cerro Prieto geothermal field, Mexico, II. Isotopic geochemistry. Geotherm. Resourc. Counc. Trans., 2:513-516.

O'Neil, J. R., Adami, L. H., and Epstein, S., 1975. Revised value for the $\mathrm{O}^{18}$ fractionation between $\mathrm{CO}_{2}$ and water at $25^{\circ} \mathrm{C}$. U.S. Geol. Surv. J. Res., 3:623-624.

O'Neil, J. R., Clayton, R. N., and Mayeda, T. K., 1969. Oxygen isotope fractionation in divalent metal carbonates. J. Chem. Phys., $51: 5547-5558$.

Sharman, G., 1976. The plate tectonic evolution of the Gulf of California [Ph.D. Dissert.]. University of California, San Diego.

Siever, R., 1962 . Silica solubility, $0^{\circ}-200^{\circ} \mathrm{C}$, and the diagenesis of siliceous sediments. J. Geol., 70:127-150.

Spiess, F. N., Macdonald, K. C., Atwater, T., Ballard, R., Carranza, A., Cordoba, D., Cox, C., Diaz-Garcia, V. M., Francheteau, J., Guerrero, J., Hawkins, J., Haymon, R., Hessler, R., Juteau, T., Kastner, M., Larson, R., Luyendyk, B., Macdougall, J. D., Miller, S., Normark, W., Orcutt, J., and Rangin, C., 1980. East Pacific Rise: hot springs and geophysical experiments. Science, 207:1421-1433.

Stakes, D. S., and O'Neil, J. R., 1982. Mineralogy and stable isotope geochemistry of hydrothermally altered oceanic rocks. Earth Planet. Sci. Lett., 57:285-304.

Syers, J. K., Chapman, S. L., Jackson, M. L., Rex, R. W., Clayton, R. N., 1968. Quartz isolation from rocks, sediments and soils for determination of oxygen isotope composition. Geochim. Cosmochim. Acta, 32:1022-1025.

Thompson, A. P., 1971. Analcite-albite equilibria at low temperatures. Am. J. Sci., 271:79-92.

van Andel, Tj. H., 1964. Recent marine sediments of Gulf of California. In Van Andel, Tj. H., and Shor, G. G. (Eds.), Marine Geology of the Gulf of California. Am. Assoc. Pet. Geol. Mem. 3: 216-310.

Weiss, R. F., Lonsdale, P. F., Lupton, J. E., Bainbridge, A. E., and Craig, H., 1977. Hydrothermal plumes in the Galapagos Rift. Nature, 267:600-603.

Wenner, D. B., and Taylor, H. P., Jr., 1971. Temperatures of serpentinization of ultramafic rocks based on $\mathrm{O}^{18} / \mathrm{O}^{16}$ fractionation between coexisting serpentine and magnetite. Contrib. Mineral. Petrol., 32:165-185.

Wilde, P., Menard, H. W., and Sharman, G., 1973. Temperature-salinity-depth profiles from deeps in the Gulf of California. Eos, Trans. Am. Geophys. Union, 54:322.

Williams, D. L., Becker, K., Lawver, L. A., and Von Herzen, R. P., 1979. Heat flow at the spreading centers of the Guaymas Basin, Gulf of California. J. Geophys. Res., 84:6757-6769. 


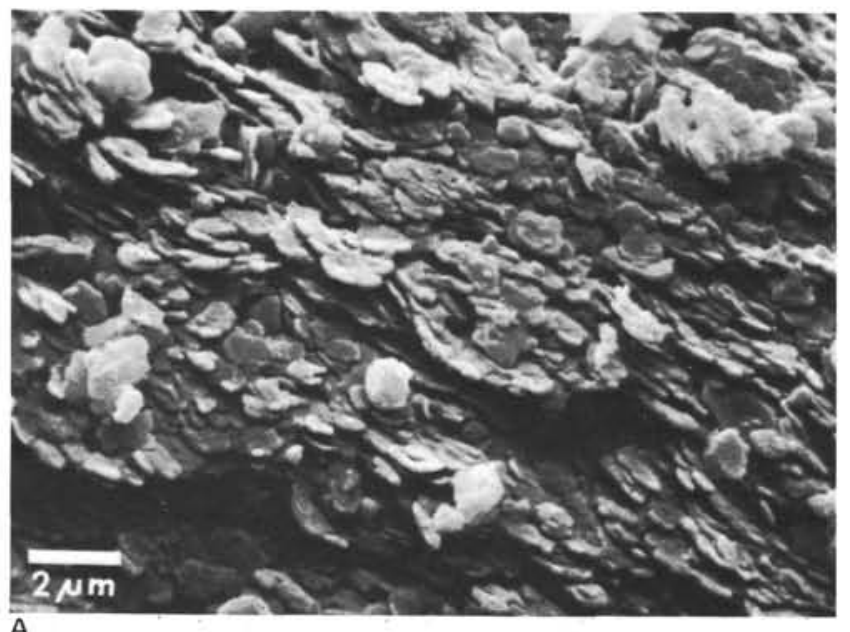

A

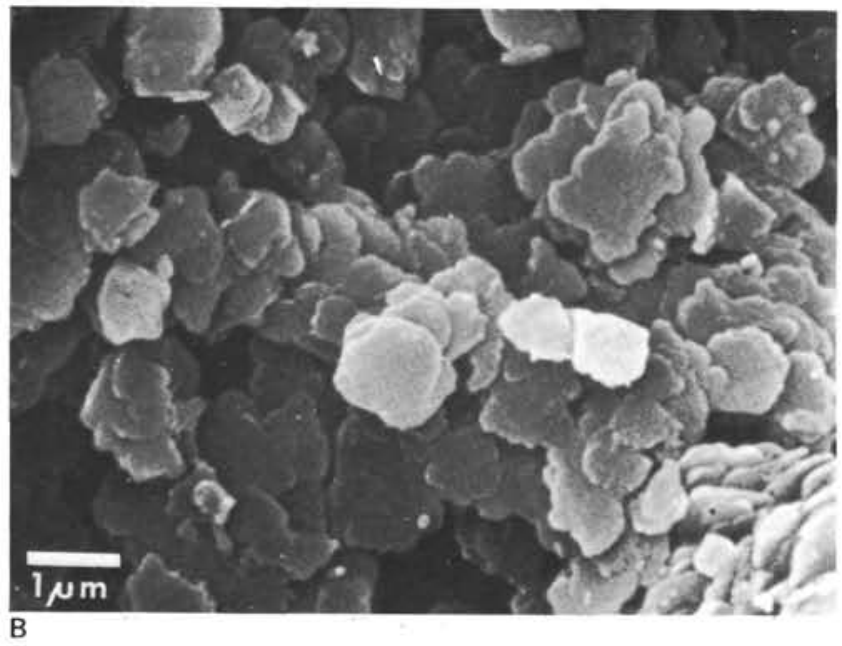

Figure 5. Scanning electron microscope photographs of separated chlorite shown in Figure 4: (A) general view, and (B) close-up view of chlorite crystals.
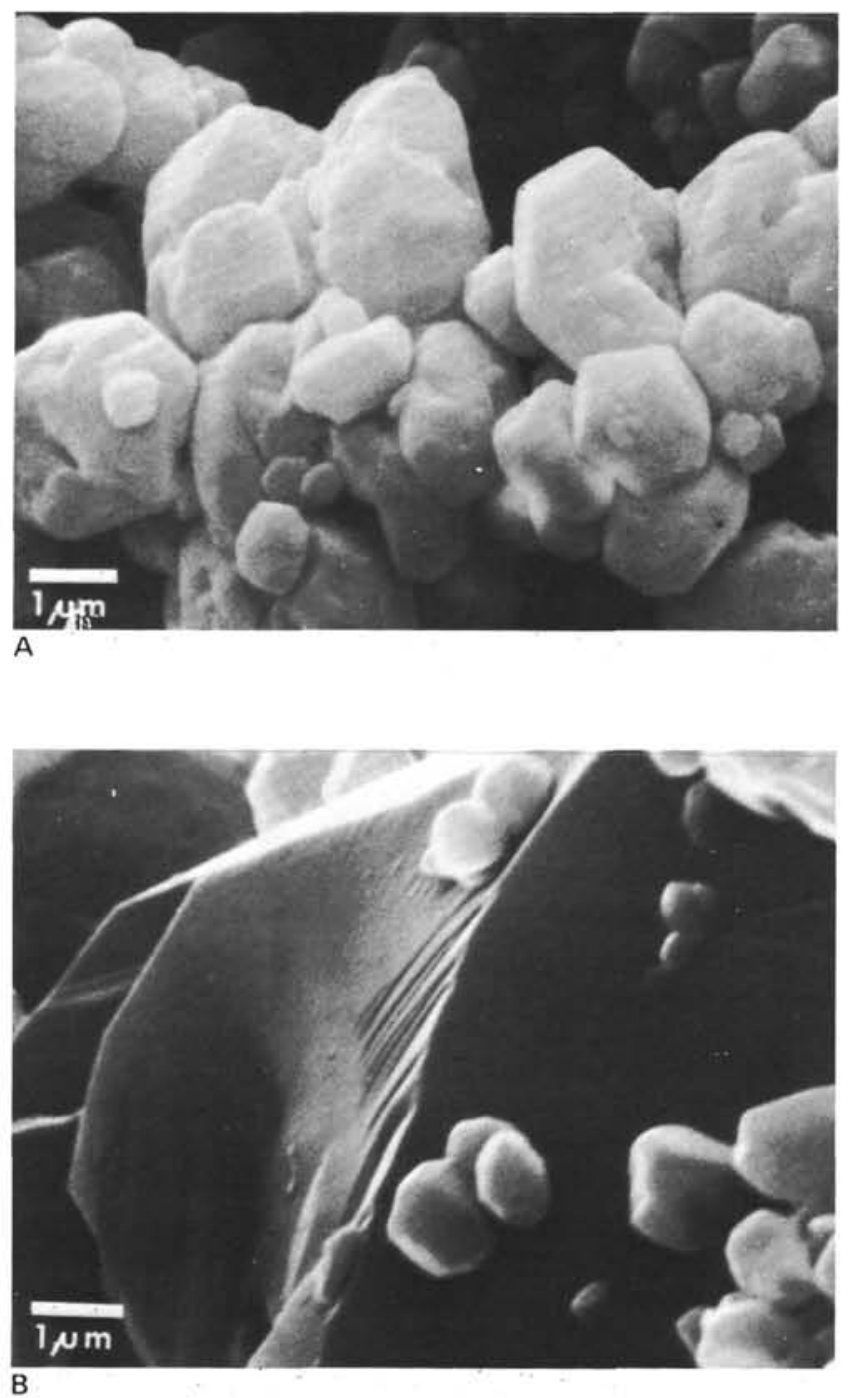

Figure 6. Scanning electron microscope photographs of separated hydrothermal quartz, which coexists with the chlorite shown in Figures 4 and 5: (A) cluster of small euhedral quartz crystals; (B) two generations of hydrothermal euhedral quartz crystals. 
APPENDIX A

X-Ray Diffraction Data, Site 477

\begin{tabular}{|c|c|c|c|c|c|c|c|c|c|c|c|c|c|c|c|c|c|}
\hline \multirow{2}{*}{$\begin{array}{l}\text { Sub-bottom } \\
\text { Depth (m) }\end{array}$} & \multirow{2}{*}{$\begin{array}{c}\text { Sample } \\
\text { (interval in } \mathrm{cm} \text { ) }\end{array}$} & \multicolumn{2}{|c|}{ Feldspars } & \multicolumn{2}{|c|}{ Silica } & \multirow[b]{2}{*}{ Q:F } & \multicolumn{3}{|c|}{ Clay Minerals } & \multicolumn{2}{|c|}{ Zeolites } & \multicolumn{2}{|c|}{$\begin{array}{c}\text { Carbon- } \\
\text { ates }\end{array}$} & \multirow[b]{2}{*}{ Pyrite } & \multirow{2}{*}{$\begin{array}{l}\text { Gypsum or } \\
\text { Anhydrite }\end{array}$} & \multirow[b]{2}{*}{ Other Minerals } & \multirow[b]{2}{*}{ Notes } \\
\hline & & $\mathrm{Pl}$ & $\mathrm{AF}$ & Q & A & & $\mathrm{s}$ & 1 & $\mathrm{Ch} / \mathrm{K}$ & $\mathrm{Cpt}$ & Am & c & D & & & & \\
\hline \multicolumn{18}{|l|}{ Hole 477} \\
\hline 3.3 & $2-2,84-86$ & $\mathrm{x}$ & $\mathrm{x}$ & $\mathrm{x}$ & $\mathrm{xx}$ & $\mathrm{Q}<\mathrm{F}$ & $\mathrm{x}$ & $\mathrm{x}$ & $\mathrm{x}$ & tr. & & $\mathrm{x}$ & & tr. & & & 1 \\
\hline 5.4 & $2-3,140-150$ & $\mathrm{x}$ & $x$ & $\mathrm{x}$ & $\mathrm{xx}$ & $Q \approx F$ & $\mathrm{x}$ & $\mathrm{x}$ & $\mathrm{x}$ & tr. & & & & tr. & & & \\
\hline 11.9 & $3-1,140-150$ & $\underset{x}{x}$ & $\mathrm{x}$ & $x_{x}^{x}$ & $\begin{array}{cc}x x \\
x x\end{array}$ & $Q=F$ & $\underset{x}{x}$ & $\underset{x}{x}$ & $\underset{x}{x}$ & $\mathrm{x}$ & & $x$ & & tr. & & & \\
\hline $\begin{array}{l}12.7 \\
15.2\end{array}$ & $\begin{array}{l}3-2,72-74 \\
3-4,21-22\end{array}$ & $\begin{array}{l}\mathrm{X} \\
\mathrm{x}\end{array}$ & tr. & $\begin{array}{l}x \\
x\end{array}$ & $\begin{array}{l}X X \\
x x\end{array}$ & $\begin{array}{l}Q<F \\
Q<F\end{array}$ & $\begin{array}{l}\mathrm{x} \\
\mathrm{x}\end{array}$ & $\underset{x}{x}$ & $\begin{array}{l}\mathrm{x} \\
\mathrm{x}\end{array}$ & to & & $\begin{array}{l}x \\
x\end{array}$ & & tr. & & & $S=75 \%$ expandable layers in mixed-layer $S / 1$ \\
\hline $\begin{array}{l}15.2 \\
20.5\end{array}$ & $4-1,51-53$ & $\hat{x}$ & & $\hat{x}$ & $\hat{x} \hat{x}$ & $Q<F$ & $\hat{x}$ & $\hat{x}$ & & $\stackrel{\text { tr. }}{\mathrm{X}}$ & & $\begin{array}{l}x \\
\mathrm{x}\end{array}$ & & & & & \\
\hline 21.3 & $4-1,133-140$ & $\mathrm{x}$ & $\mathrm{x}$ & $\mathrm{x}$ & $\mathrm{xx}$ & $Q=F$ & tr. & tr. & & $\mathrm{x}$ & & & & $\mathrm{x}$ & & & \\
\hline 30.9 & $5-1,140-150$ & $\underset{x}{x}$ & & $\underset{x}{x}$ & $\mathrm{XX}$ & $Q=F$ & $x$ & tr. & & $\mathrm{x}$ & & $\underset{x}{x}$ & & & & & f \\
\hline 31.5 & $\begin{array}{r}5-2,53-55 \\
7-1,36-38\end{array}$ & $\begin{array}{l}x \\
x\end{array}$ & & $\underset{x x}{x}$ & $\underset{x}{x x}$ & $Q<F$ & $\begin{array}{l}x \\
x\end{array}$ & $\underset{t r}{X}$ & $\mathrm{x}$ & $\mathrm{x}$ & & $\mathrm{x}$ & & $\begin{array}{l}\mathrm{x} \\
\mathrm{x}\end{array}$ & $x$ & & $\mathrm{~S}=$ no Illite layers \\
\hline $\begin{array}{l}48.9 \\
49.9\end{array}$ & $\begin{array}{l}7-1,36-38 \\
7-1,140-150\end{array}$ & $\underset{x}{x}$ & & $\begin{array}{l}\mathrm{XX} \\
\mathrm{XX}\end{array}$ & $\begin{array}{c}X \\
\text { tr. }\end{array}$ & $\begin{array}{l}Q>F \\
Q=F\end{array}$ & $\underset{x}{x}$ & & & & $\mathrm{x}$ & $x$ & tr. & $\underset{x}{x}$ & $\begin{array}{l}x \\
x\end{array}$ & An amphibole & $\begin{array}{l}S=\text { no llite layers } \\
S=\text { no } 1 \text { layers, well crystallized }\end{array}$ \\
\hline $\begin{array}{l}50.4 \\
\text { Sill }\end{array}$ & $7-2,35-37$ & $\mathrm{xx}$ & & $\mathrm{xx}$ & & $Q \leq F$ & $\mathrm{xx}$ & tr. & & & & $x$ & & $\mathrm{x}$ & $\mathrm{x}$ & Possibly goethite & $\mathrm{S}=$ no 1 layers, well crystallized \\
\hline 105.6 & $15-1,7-9$ & tr. & $\mathrm{x}$ & $\mathrm{x}$ & & $Q>F$ & $\mathrm{x}$ & & tr. & & & & $\mathrm{x}$ & $\mathrm{x}$ & & & $\mathrm{S}=$ no I l layers, well crystallized; $\mathrm{D}=$ protodolomite; $\mathrm{AF}=$ hydrothermal \\
\hline 106.3 & $15-1,126-131$ & $\mathrm{x}$ & $\mathrm{x}$ & $\mathrm{xx}$ & & $Q>F$ & $\mathrm{x}$ & tr. & tr. & & & & & $\mathrm{x}$ & $\mathrm{x}$ & & $S \approx 75 \%$ expandable layers in $S / I$ \\
\hline 115.1 & $16-1,10-11$ & $\mathrm{x}$ & tr. & $\mathrm{x}$ & $\mathrm{x}$ & $Q>F$ & tr. & tr. & & & & & $\mathrm{xx}$ & $x$ & $x$ & & $\begin{array}{l}\mathrm{D}=\text { protodolomite; gypsum and anhydrite } \\
\text { First appearance of greenschist-facies chlorite; } \mathrm{Q}>\mathrm{Ch} \geq \mathrm{Pl} ; \mathrm{Pl}=\text { albite }\end{array}$ \\
\hline $\begin{array}{l}120.9 \\
126.5\end{array}$ & $\begin{array}{l}16-4,140-150 \\
17-2,51-53\end{array}$ & $\begin{array}{l}\mathrm{x} \\
\mathrm{x}\end{array}$ & $\underset{\text { tr. }}{\mathrm{X}}$ & $\begin{array}{l}x \\
x\end{array}$ & & $\begin{array}{l}Q>F \\
Q=F\end{array}$ & & $\begin{array}{l}x \\
x\end{array}$ & $\begin{array}{l}\mathrm{x} \\
\mathrm{x}\end{array}$ & & & & & $\begin{array}{l}\mathrm{x} \\
\mathrm{x}\end{array}$ & $\underset{x}{x}$ & & First appearance of greenschist-facies chlorite; $\mathrm{Q}>\mathrm{Ch} \geq \mathrm{Pl} ; \mathrm{Pl}=$ albite \\
\hline 127.4 & $17-2,140-150$ & $\hat{x}$ & tr. & $\hat{x}$ & & $Q>F$ & tr. & $\hat{\text { tr. }}$ & $\hat{x}$ & & & & & $\hat{x}$ & $\hat{x}$ & Some epidote (possibly natrolite) & \\
\hline 144.9 & $19-1,140-150$ & $\mathrm{x}$ & tr. & $\mathrm{x}$ & & $Q \leq F$ & tr. & tr. & $\mathrm{x}$ & & & $\mathrm{x}$ & & & $\mathrm{x}$ & Some epidote and sphene & \\
\hline 154.4 & $20-1,140-150$ & $\mathrm{x}$ & tr. & $\mathrm{x}$ & & $Q \simeq F$ & & tr. & $\mathrm{x}$ & & & $\mathrm{x}$ & & $\mathrm{x}$ & $\mathrm{x}$ & Sphene and some epidote & \\
\hline 173.4 & $22-1,140-150$ & $\mathrm{xx}$ & & $\mathrm{xx}$ & & $Q=F$ & & & $\mathrm{x}$ & & & $\mathrm{x}$ & & $\mathrm{x}$ & $\mathrm{x}$ & Sphene & \\
\hline 181.5 & $23-0, \mathrm{CC}$ & $\mathrm{x}$ & & $\mathrm{x}$ & & $Q \approx F$ & & & $\mathrm{xx}$ & & & $\mathrm{x}$ & & $\mathrm{x}$ & & Much pyrrhotite & \\
\hline 181.8 & $23-1,34-36$ & $\mathrm{x}$ & & $\mathrm{x}$ & & $Q=F$ & & & $\mathrm{xx}$ & & & $\mathrm{x}$ & & $\mathrm{x}$ & & Pyrrhotite & \\
\hline \multicolumn{18}{|l|}{ Hole 477A } \\
\hline 191.9 & $5-1,92-94$ & $\mathrm{x}$ & & $\mathrm{xx}$ & & $Q>F$ & & & $x x$ & & & & & $\mathrm{x}$ & & Epidote & \\
\hline 192.1 & $5-1,114-120$ & $\mathrm{xx}$ & & $\mathrm{xx}$ & & $Q \approx F$ & & & $\mathrm{xx}$ & & & & & tr. & & Some epidote & $P I=$ albite \\
\hline 209.5 & $6, \mathrm{CC}(1-3)$ & $\mathrm{xx}$ & & $\mathrm{xx}$ & & $Q=F$ & & & $\mathrm{x}$ & & & & & $\mathrm{x}$ & & & \\
\hline 209.5 & $6, \mathrm{CC}(4-6)$ & $\mathrm{x}$ & & $\mathrm{xx}$ & & $Q>F$ & & & $x x$ & & & & & $\mathrm{x}$ & & & \\
\hline 200.6 & $6, C C \cdot(114-120)$ & $x x$ & & $\mathrm{x}$ & & $Q<F$ & & & $\mathrm{xx}$ & & & & & $\mathrm{x}$ & & Some epidote & \\
\hline 210.5 & $7-1,50-52$ & $x x$ & & $x x$ & & $Q=F$ & & & $\mathrm{x}$ & & & & & $\mathrm{x}$ & & Some epidote & \\
\hline 228.5 & $8, \mathrm{CC}$ & $\mathrm{xx}$ & & $x x$ & & $\mathrm{Q} \simeq \mathrm{F}$ & & & $\hat{x}$ & & & & & $\mathrm{x}$ & & Epidote & \\
\hline 229.7 & $9-1,69-71$ & $\mathrm{xx}$ & & $\mathrm{x}$ & & $Q<F$ & & & $\hat{x}$ & & & & & $\mathrm{x}$ & & Epidote & \\
\hline 229.8 & $9-1,84-86$ & $\mathrm{xx}$ & & $x x$ & & $Q \simeq F$ & & & $\hat{\mathrm{x}}$ & & & & & $\mathrm{x}$ & & Epidote & \\
\hline 239.6 & $10-1,110-120$ & $\mathrm{x}$ & & $\mathrm{xx}$ & & $Q>F$ & & & $x x$ & & & & & $\mathrm{x}$ & & Some pyrrhotite; epidote & \\
\hline 247.5 & $10, \mathrm{CC}$ & $\hat{x x}$ & & $\mathrm{xx}$ & & $Q \leq F$ & & & $\mathrm{x}$ & & & & & & & Some epidote; pyrrhotite & \\
\hline
\end{tabular}

Note: $\mathrm{Q}=$ quartz, $\mathrm{A}=$ opal- $\mathrm{A}, \mathrm{F}=$ feldspars $(\mathrm{Pl}=$ plagioclase, $\mathrm{AF}=$ alkali feldspar), $\mathrm{S}=$ smectite, $\mathrm{I}=$ illite, $\mathrm{Ch}=$ chlorite, $\mathrm{K}=$ kaolinite, $\mathrm{Cpt}=$ clinoptilolite, $\mathrm{Am}=$ analcime, $\mathrm{C}=$ calcite, $\mathrm{D}=$ dolomite, tr. $=$ traces, $\mathrm{X}=$ common, $\mathrm{XX}=$ abundant. Blanks indicate that the mineral was not observed. 
APPENDIX B

X-Ray Diffraction Data, Site 481

\begin{tabular}{|c|c|c|c|c|c|c|c|c|c|c|c|c|c|c|c|c|c|}
\hline \multirow{2}{*}{$\begin{array}{l}\text { Sub-bottom } \\
\text { Depth (m) }\end{array}$} & \multirow{2}{*}{$\begin{array}{c}\begin{array}{c}\text { Sample } \\
\text { (interval in } \mathrm{cm} \text { ) }\end{array}\end{array}$} & \multicolumn{2}{|c|}{ Feldspars } & \multicolumn{3}{|c|}{ Silica } & \multirow[b]{2}{*}{ Q:F } & \multicolumn{3}{|c|}{ Clay Minerals } & \multicolumn{2}{|c|}{ Zeolites } & \multicolumn{2}{|c|}{ Carbonates } & \multirow[b]{2}{*}{ Pyrite } & \multirow{2}{*}{$\begin{array}{l}\text { Gypsum or } \\
\text { Anhydrite }\end{array}$} & \multirow[b]{2}{*}{ Notes } \\
\hline & & $\mathrm{Pl}$ & $\mathrm{AF}$ & Q & Opal-CT & A & & $\mathrm{s}$ & I & $\mathrm{Ch} / \mathrm{K}$ & $\mathrm{Cpt}$ & $\mathrm{Am}$ & $\mathrm{C}$ & Sd & & & \\
\hline \multicolumn{18}{|l|}{ Hole 481} \\
\hline 2.2 & $1-2,66-68$ & $\mathrm{x}$ & $\mathrm{x}$ & $\mathrm{x}$ & & $x x$ & $\mathrm{Q}<\mathrm{F}$ & $\mathrm{x}$ & tr. & tr. & tr. & & $\mathrm{x}$ & & tr. & \multirow{23}{*}{$\mathrm{x}$} & \\
\hline 4.9 & $2-1,10-12$ & $\mathrm{x}$ & $x$ & $x$ & & $\mathrm{xx}$ & $Q<F$ & $\mathrm{x}$ & tr. & tr. & tr. & & $\mathrm{x}$ & & tr. & & \\
\hline 6.2 & $2-1,145-150$ & $\mathrm{x}$ & $x$ & $x$ & & $\mathrm{xx}$ & $Q<F$ & $\mathrm{x}$ & $x$ & $\mathrm{x}$ & tr. & & $x$ & & tr. & & \\
\hline 6.3 & $2-2,8-9$ & $\mathrm{x}$ & $x$ & $\mathrm{x}$ & & $x x$ & $Q \leq F$ & $\mathrm{x}$ & $\hat{x}$ & tr. & $\mathrm{x}$ & & $x x$ & & tr. & & \\
\hline 8.2 & $2-3,41-43$ & $\mathrm{x}$ & & $\mathrm{x}$ & & $\mathrm{xx}$ & $Q=F$ & tr. & tr. & tr. & $\mathrm{x}$ & & $x$ & & tr. & & \\
\hline 10.8 & $3-1,129-131$ & $\mathrm{x}$ & $\mathrm{x}$ & $\mathrm{x}$ & & $\mathrm{x}$ & $Q \geq F$ & $x$ & $x$ & tr. & tr. & & $x x$ & & tr. & & \\
\hline 12.1 & $3-2,110-112$ & $\mathrm{x}$ & $\mathrm{x}$ & $\mathrm{x}$ & & $\mathrm{x}$ & $Q \leq F$ & $x$ & $\mathrm{x}$ & tr. & tr. & & $\mathrm{xx}$ & & tr. & & $\mathrm{S}=75 \%$ to $80 \%$ expandable layers in mixed layer $\mathrm{S} / \mathrm{I}$ \\
\hline 14.5 & $41,23-25$ & $\mathrm{x}$ & $\mathrm{x}$ & $\mathrm{x}$ & & $\mathrm{x}$ & $Q>F$ & $\mathrm{x}$ & $\hat{x}$ & $\mathrm{x}$ & tr. & & $x$ & & tr. & & \\
\hline 14.7 & $41,40-42$ & $\mathrm{x}$ & $\mathrm{x}$ & $\mathrm{x}$ & & $x x$ & $Q<F$ & $\mathrm{x}$ & $\hat{x}$ & tr. & $\mathrm{x}$ & & $\mathrm{xx}$ & & tr. & & \\
\hline 23.4 & $6-1,15-16$ & $\mathrm{x}$ & & $\mathrm{x}$ & & $\mathrm{xx}$ & $Q>F$ & $\hat{x}$ & $\ddot{x}$ & tr. & $\hat{x}$ & & $x$ & & tr. & & \\
\hline 29.2 & $7-1,72-74$ & $\hat{x}$ & $\mathrm{x}$ & $\mathrm{x}$ & & $\mathrm{xx}$ & $Q=F$ & $\hat{x}$ & $\mathrm{x}$ & $\mathrm{x}$ & tr. & & $\mathrm{x}$ & & $\mathrm{x}$ & & \\
\hline 33.2 & $7, C C(17-19)$ & $\hat{x}$ & & $\hat{x}$ & & $\mathrm{xx}$ & $\mathrm{Q}>\mathrm{F}$ & $\hat{x}$ & $\hat{x}$ & tr. & & & $\mathrm{x}$ & & & & \\
\hline 34.1 & $8-1,87-89$ & $\hat{x}$ & $\mathrm{x}$ & $\mathrm{x}$ & & $\mathrm{xx}$ & $Q>F$ & $\hat{x}$ & $\mathrm{x}$ & tr. & tr. & & $\mathrm{x}$ & & tr. & & \\
\hline 36.2 & $8-2,143-145$ & $\hat{x}$ & & $\hat{x}$ & & $\mathrm{x}$ & $Q>\mathrm{F}$ & $\hat{x}$ & $\hat{x}$ & $\mathrm{xx}$ & & & & & tr. & & \\
\hline 36.3 & $8-3,3-5$ & tr. & & $\hat{\mathrm{x}}$ & & & $Q>F$ & $\hat{x}$ & $\mathrm{x}$ & $\mathrm{xx}$ & & & & & tr. & & Much chlorite in clay fraction $(\mathrm{Mg}>\mathrm{Fe}$ ), moderate $\mathrm{S} / \mathrm{I}$. Possible an altered ash layer \\
\hline 36.4 & $8-3,9-11$ & $\mathrm{x}$ & & $\mathrm{xx}$ & & & $Q>\mathrm{F}$ & $\hat{x}$ & & $\mathrm{xx}$ & & & & & & & \\
\hline 37.4 & $8-3,112-113$ & $\hat{\mathrm{x}}$ & & $\mathrm{x}$ & & $\mathrm{x}$ & $Q=F$ & $\hat{\mathrm{x}}$ & tr. & tr. & $\mathrm{x}$ & & $\mathrm{x}$ & & $\mathrm{x}$ & & \\
\hline 37.8 & $8-\mathrm{CC}, 5-7$ & $\hat{x}$ & & $\hat{x}$ & & $\mathrm{x}$ & $Q=F$ & $\hat{x}$ & tr. & tr. & $\hat{x}$ & & $\mathrm{x}$ & & & & \\
\hline 39.5 & $9-1,140-150$ & $\hat{x}$ & $\mathrm{x}$ & $\hat{x}$ & & $\hat{x}$ & $Q<F$ & $\hat{\mathrm{x}}$ & $\mathrm{x}$ & tr. & & & $\mathrm{x}$ & & $\mathrm{x}$ & & \\
\hline 43.2 & $10-1,41-42$ & $\hat{\mathrm{x}}$ & & $\hat{x}$ & & $\hat{x}$ & $Q<F$ & $\hat{\mathrm{x}}$ & $\hat{x}$ & & & & $\hat{x}$ & & $\mathrm{x}$ & & \\
\hline 43.7 & $10-1,97-99$ & $\mathrm{x}$ & $\mathrm{x}$ & $\mathrm{x}$ & & $\hat{x}$ & $Q<F$ & $\mathrm{x}$ & & $\mathrm{x}$ & tr. & & $\hat{x}$ & & & & $\mathrm{~S}=75 \%$ to $80 \%$ expandable layers in mixed layer $\mathrm{S} / \mathrm{I}$ \\
\hline 46.6 & $10-3,86-88$ & $\mathrm{x}$ & & $\mathrm{x}$ & & $\mathrm{x}$ & $Q>\mathrm{F}$ & $\mathrm{x}$ & $\mathrm{x}$ & & & & tr. & & $\mathrm{x}$ & & \\
\hline 47.7 & $11-1,23-25$ & $\ddot{x}$ & & $\hat{x}$ & & $\hat{x}$ & $Q=F$ & $\mathrm{x}$ & $\hat{x}$ & & & & $x$ & & $\hat{x}$ & & \\
\hline \multicolumn{18}{|l|}{ Hole 481A } \\
\hline 44.1 & $1-2,56-58$ & $\mathrm{x}$ & $\mathrm{x}$ & $\mathrm{x}$ & & $\mathrm{x}$ & $Q \approx F$ & $\mathrm{x}$ & $\mathrm{x}$ & $\mathrm{x}$ & tr. & & & & $\mathrm{x}$ & \multirow{8}{*}{$\mathrm{x}$} & \multirow{8}{*}{$S=75 \%$ expandable layers in mixed layer $S / I$} \\
\hline 52.4 & $2-1,87-88$ & $\hat{x}$ & $\hat{x}$ & $\hat{x}$ & & $\hat{x}$ & $Q \approx F$ & $\hat{x}$ & $\hat{x}$ & $\hat{\text { tr. }}$ & $x$ & & & & & & \\
\hline 62.0 & $3-1,101-103$ & $\hat{x}$ & $\hat{x}$ & $\hat{x}$ & & $\hat{x}$ & $Q \approx F$ & $\hat{x}$ & $\hat{x}$ & tr. & $\hat{\mathrm{tr}}$. & & & & & & \\
\hline 70.7 & $4-1,19-21$ & $\mathrm{x}$ & & $\mathrm{x}$ & & $\mathrm{x}$ & $Q>F$ & $\mathrm{x}$ & & $\mathrm{x}$ & tr. & & $\mathrm{x}$ & & $\mathrm{x}$ & & \\
\hline 73.7 & $4-3,17-19$ & $\mathrm{x}$ & & $\mathrm{x}$ & & $\mathrm{x}$ & $Q>F$ & $\mathrm{x}$ & & $\mathrm{x}$ & tr. & & $\mathrm{x}$ & & $\mathrm{x}$ & & \\
\hline 82.1 & $5-2,57-58$ & $\mathrm{x}$ & $\mathrm{x}$ & $\mathrm{x}$ & & $x x$ & $Q<F$ & $\mathrm{x}$ & tr. & tr. & tr. & & $x$ & & & & \\
\hline 89.4 & $5-7,35-37$ & $\mathrm{x}$ & $\mathrm{x}$ & $\mathrm{x}$ & & $x x$ & $\mathrm{Q}>\mathrm{F}$ & $x$ & tr. & tr. & $\mathrm{x}$ & & $\mathrm{x}$ & & & & \\
\hline 92.8 & $6-3,28-30$ & $\mathrm{x}$ & & $\mathrm{x}$ & & $\mathrm{xx}$ & $\mathrm{Q}>\mathrm{F}$ & $\mathrm{x}$ & tr. & tr. & $\mathrm{x}$ & & tr. & & & & \\
\hline 96.1 & $6-5,58-60$ & $\mathrm{x}$ & $\mathrm{x}$ & $\mathrm{x}$ & & $\mathrm{xx}$ & $Q<F$ & $\mathrm{x}$ & tr. & tr. & $\mathrm{x}$ & & tr. & & & & \multirow{4}{*}{$\mathrm{S}=75 \%$ expandable layers in $\mathrm{S} / \mathrm{L}$. Significant amounts of clinoptilolite } \\
\hline 98.6 & $6-7,7-9$ & $\mathrm{x}$ & & $x$ & & $\mathrm{xx}$ & $Q>F$ & tr. & tr. & tr. & $x$ & & & & & & \\
\hline 102.9 & $7-3,85-87$ & $\mathrm{x}$ & & $\mathrm{x}$ & & $\mathrm{xx}$ & $\mathrm{Q} \geq \mathrm{F}$ & $\mathrm{x}$ & tr. & tr. & $\mathrm{x}$ & & tr. & & tr. & & \\
\hline 107.5 & $7-6,98-100$ & $\mathrm{x}$ & & $\mathrm{x}$ & & $\mathrm{xx}$ & $Q \geq F$ & $x$ & tr. & tr. & $\mathrm{x}$ & & tr. & & tr. & & \\
\hline 112.4 & $8-3,85-87$ & $\mathrm{x}$ & $\mathrm{x}$ & $\mathrm{x}$ & & $\mathrm{xx}$ & $Q \geq F$ & $x$ & tr. & tr. & $\mathrm{x}$ & & & & tr. & $\mathrm{x}$ & \multirow{5}{*}{$\begin{array}{l}\text { Less clinoptilolite than in above samples } \\
\text { Less clinoptilolite than in above samples } \\
\text { Less clinoptilolite than in above samples. Small amounts of opal-A } \\
\text { Less clinoptilolite than in above samples. Small amounts of opal-A }\end{array}$} \\
\hline 116.3 & $8-6,25-27$ & $\mathrm{x}$ & & $\mathrm{x}$ & & $\mathrm{x}$ & $\mathrm{Q}>\mathrm{F}$ & $\mathrm{x}$ & tr. & & $\mathrm{x}$ & & tr. & & & & \\
\hline 126.1 & $9-6,56-58$ & $\mathrm{x}$ & $\mathrm{x}$ & $\mathrm{x}$ & & $\mathrm{x}$ & $Q>F$ & $x$ & tr. & & $x$ & & $x$ & & & & \\
\hline 132.8 & $10-4,82-84$ & $\mathrm{x}$ & $\mathrm{x}$ & $\mathrm{x}$ & & $\mathrm{x}$ & $Q=F$ & $x$ & tr. & & $\mathrm{x}$ & & $\mathrm{x}$ & & $\mathrm{x}$ & & \\
\hline 133.8 & $10-5 ; 24-26$ & $\mathrm{x}$ & & $\mathrm{x}$ & & tr. & $Q \geq F$ & $\mathrm{x}$ & $\mathrm{x}$ & & $\mathrm{x}$ & & & & & & \\
\hline
\end{tabular}




\begin{tabular}{|c|c|c|c|c|c|c|c|c|c|c|c|c|c|c|c|c|c|}
\hline 139.9 & $11-2,144-146$ & $\mathrm{x}$ & & $x \mathbf{x}$ & & tr. & $\mathrm{Q}>\mathrm{F}$ & $\mathrm{x}$ & tr. & & & & $\mathrm{x}$ & & $\mathrm{x}$ & & No clinoptilolite \\
\hline 140.1 & $11-3,9-11$ & $\mathrm{x}$ & & $\mathrm{xx}$ & & & $Q>F$ & $\mathrm{x}$ & tr. & & tr. & & $\mathrm{x}$ & & & $\mathrm{x}$ & No opal-A \\
\hline 151.4 & $12-4,38-40$ & $\mathrm{x}$ & & $\mathrm{XX}$ & & & $Q \geq F$ & $\mathrm{x}$ & tr. & & & & $\mathrm{x}$ & & & $\mathrm{x}$ & \\
\hline 152.9 & $12-5,39-41$ & $x \mathrm{x}$ & & $x x$ & & & $Q<F$ & $\mathrm{x}$ & & & & & & & $\mathrm{x}$ & & \\
\hline 157.2 & $13-1,114-116$ & $\mathrm{XX}$ & & $\mathrm{xx}$ & & & $\mathrm{Q}<\mathrm{F}$ & $\mathrm{x}$ & tr. & & & & $\mathrm{x}$ & & $\mathrm{x}$ & $\mathrm{x}$ & Feldspar and quartz dominate; better crystallized S \\
\hline 161.2 & $13-4,67-69$ & $\mathrm{xx}$ & $\mathrm{x}$ & $\mathrm{xx}$ & & & $Q<F$ & $\mathrm{x}$ & tr. & & & & $\mathrm{x}$ & & $\mathrm{x}$ & & \\
\hline 163.7 & $13, \mathrm{CC}(20)$ & $x \mathrm{x}$ & $\mathrm{x}$ & $x x$ & & & $Q<F$ & $\mathrm{x}$ & $\mathrm{x}$ & & & & $\mathrm{x}$ & & $\mathrm{x}$ & & Well-crystallized clay minerals \\
\hline 166.0 & $14-1,49-51$ & $x \mathrm{x}$ & & $\mathrm{xx}$ & & & $Q \simeq F$ & $\mathrm{x}$ & $\mathrm{x}$ & & & & $\mathrm{x}$ & & & & Mainly' quartz and feldspar; well-crystallized 1 \\
\hline 166.9 & $14-1,131-141$ & $\mathrm{xx}$ & & $\mathrm{xx}$ & & & $Q=F$ & $\mathrm{x}$ & $\mathrm{x}$ & & & & $\mathrm{x}$ & & & & Mainly quartz and feldspar; well-crystallized I \\
\hline 168.0 & $14-2,99-101$ & $\mathrm{xx}$ & & $x \mathrm{x}$ & & & $Q \approx F$ & $\mathrm{x}$ & tr. & & & & & & & & Mainly quartz and feldspar; well-crystallized S \\
\hline 168.4 & $14-2,141-143$ & $\mathrm{xx}$ & & $\mathrm{xx}$ & $\mathrm{x}$ ? & & $Q=F$ & tr. & tr. & & & & & & & $\mathrm{x}$ & Mainly quartz and feldspar; small amounts of $S$ and $I$ well crystallized \\
\hline 169.0 & $14-3,47-49$ & $\mathrm{xx}$ & & $\mathrm{xx}$ & & & $Q \approx F$ & tr. & tr. & tr. & & & tr. & & $\mathrm{x}$ & $\mathrm{x}$ & Mainly quartz and feldspar; small amounts of $\mathrm{S}$ and $\mathrm{I}$ well crystallized \\
\hline 169.8 & $14-3,125-127$ & $\mathrm{xx}$ & & $\mathrm{xx}$ & & & $Q \simeq F$ & & $\mathrm{x}$ & $\mathrm{x}$ & & & $\mathrm{x}$ & & $\hat{\mathrm{x}}$ & $\hat{x}$ & Mainly quartz and feldspar; well-crystallized $\mathrm{I}$ and chlorite $(\mathrm{Mg} \simeq \mathrm{Fe}$ ) \\
\hline 169.9 & $14-3,140-150$ & $\mathrm{xx}$ & & $\mathrm{xx}$ & & & $Q \geq F$ & tr. & $\mathrm{x}$ & $\mathrm{x}$ & & $\mathrm{x}$ & $\mathrm{x}$ & $\mathrm{x}$ & & & Mainly quartz and feldspar; well-crystallized $\mathrm{I}$ and chlorite $\left(\mathrm{M}_{\mathrm{g}} \simeq \mathrm{Fe}\right)$ \\
\hline 170.3 & $14-4,29-31$ & $\mathrm{xx}$ & $\mathrm{x}$ & $\mathrm{xx}$ & & & $Q \leq F$ & tr. & $\mathrm{x}$ & $\mathrm{x}$ & & & $\mathrm{x}$ & & & & Mainly quartz and feldspar; well-crystallized $\mathrm{I}$ and chlorite $\left(\mathrm{M}_{8} \simeq \mathrm{Fe}\right.$ ). Possibly some native sulfur \\
\hline 170.4 & $14-4,44-47$ & $\mathrm{xx}$ & & $\mathrm{xx}$ & & & $Q=-F$ & tr. & $\mathrm{x}$ & $\mathrm{x}$ & & & $\mathrm{x}$ & & tr. & $\mathrm{x}$ & Mainly quartz and feldspar; some well-crystallized $\mathrm{S}, \mathrm{1}, \mathrm{Ch}$ \\
\hline 170.6 & $14-4,54-55$ & $\mathrm{xx}$ & $\mathrm{x}$ & $\mathrm{xx}$ & & & $\mathrm{Q}>\mathrm{F}$ & tr. & $\hat{x}$ & tr. & & & & & & $\hat{\mathrm{x}}$ & Mainly quartz and feldspar; small amounts of well-crystallized clay minerals-mainly I. \\
\hline Sill & & & & & & & & & & & & & & & & & \\
\hline 203.6 & $18-1,14-18$ & $\mathrm{xx}$ & & $\mathrm{xx}$ & & & $Q>F$ & tr. & tr. & tr. & & & & & $\mathrm{x}$ & & Very small amounts of clay minerals \\
\hline 203.8 & $18-1,32-35$ & $\mathrm{xx}$ & $\mathrm{x}$ & $\mathrm{xx}$ & & & $Q=F$ & $\mathrm{x}$ & tr. & tr. & & & & & $\mathrm{x}$ & & Very small amounts of clay minerals; $\mathrm{S}$ is the main clay \\
\hline 204.7 & $18-1,114-116$ & $\mathrm{xx}$ & & $\mathrm{xx}$ & & & $Q>F$ & $\hat{x}$ & tr. & tr. & & & & & $\hat{x}$ & & \\
\hline 223.5 & $20-1,99-101$ & $\mathrm{x}$ & & $\mathrm{x}$ & & $\mathrm{x}$ & $Q>F$ & $\hat{x}$ & $\begin{array}{l}\text { tr. } \\
\text {. }\end{array}$ & 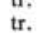 & $\mathrm{x}$ & & $\mathrm{x}$ & & $\hat{x}$ & & \\
\hline 224.2 & $20-2,14-16$ & $\mathrm{x}$ & & $\mathrm{x}$ & & $\hat{x}$ & $Q \cong F$ & $\mathrm{x}$ & & & $\hat{x}$ & & & & $\hat{x}$ & & \\
\hline 242.9 & $22-1,140-142$ & $\hat{x}$ & & $\mathrm{x}$ & & $\hat{x}$ & $Q>F$ & $\hat{x}$ & tr. & & $\hat{x}$ & & $\mathrm{xx}$ & & $\hat{x}$ & & \\
\hline 243.1 & $22-2,6-8$ & $\hat{x}$ & $\mathrm{x}$ & $\mathrm{x}$ & & $x \mathrm{x}$ & $Q \leq F$ & $\mathrm{x}$ & $\mathrm{x}$ & $\mathrm{x}$ & $\mathrm{x}$ & & $\mathrm{x}$ & $\mathrm{x}$ ? & & & $S=75 \%$ expandable layers in mixed-layer $S / 1$ \\
\hline 248.4 & $22-5,92-94$ & $\mathrm{x}$ & & $\mathrm{x}$ & & $\mathrm{x}$ & $Q \leq F$ & $\hat{x}$ & & & & & $\hat{x}$ & & $\mathrm{x}$ & & \\
\hline 262.0 & $24-1,144-146$ & $\hat{x}$ & $\mathrm{x}$ & $\hat{x}$ & & $\hat{x x}$ & $Q \leq F$ & $\hat{x}$ & $\mathrm{x}$ & & $\mathrm{x}$ & & $\hat{x}$ & $\mathrm{x}$ & & & \\
\hline 265.0 & $24-3,144-147$ & $\hat{x}$ & & $\mathrm{x}$ & & $\mathrm{x}$ & $\mathrm{Q}>\mathrm{F}$ & $\hat{x}$ & $\hat{x}$ & & $\hat{x}$ & & $x x$ & & & $\mathrm{x}$ & \\
\hline 267.3 & $24-5,76-78$ & $\hat{x}$ & & $\hat{x}$ & & $\hat{x}$ & $Q=F$ & $\hat{x}$ & $\hat{x}$ & tr. & $\hat{x}$ & & $\mathrm{x}$ & & tr. & & Significant amounts of clinoptilolite \\
\hline 270.5 & $24-7,94-96$ & $\hat{x}$ & & $\hat{x}$ & & $\mathrm{x}$ & $Q>F$ & $\hat{x}$ & tr. & tr. & $\hat{\mathrm{tr}}$. & & $\hat{x}$ & $\mathrm{x}$ ? & & & \\
\hline 271.3 & $25-1,124-126$ & $\hat{x}$ & $\mathrm{x}$ & $\mathrm{x}$ & $\mathrm{x}$ & $\hat{x}$ & $\mathrm{Q}<\mathrm{F}$ & $\hat{x}$ & $\mathrm{x}$ & $\mathrm{x}$ & $x$ & & $\hat{x}$ & & & & \\
\hline 276.7 & $25-5,66-68$ & $\hat{x}$ & & $\hat{x}$ & & $\hat{x}$ & $\mathrm{Q}>\mathrm{F}$ & $\hat{x}$ & $\hat{\text { tr. }}$ & $\hat{\mathrm{tr}}$. & & & $\hat{x}$ & & tr. & & \\
\hline 281.2 & $26-2,19-21$ & $\hat{x}$ & & $\hat{x}$ & & $\hat{x}$ & $\mathrm{Q}>\mathrm{F}$ & $\hat{x}$ & tr. & & & & $\hat{x}$ & & & & Laminated sample \\
\hline 287.9 & $26-6,90-92$ & $\hat{x}$ & $\mathrm{x}$ & $\hat{x}$ & & $\hat{x}$ & $Q>F$ & $\hat{x}$ & tr. & & tr. & & $\hat{x}$ & $\mathrm{x}$ & & & Laminated sample \\
\hline 288.5 & $26-6,140-150$ & $\hat{x}$ & & $\hat{x}$ & & $\hat{x}$ & $Q=F$ & $\hat{x}$ & tr. & & $\mathrm{x}$ & & $\hat{x}$ & & & & \\
\hline 291.0 & $27-2,52-54$ & $\hat{x}$ & & $\mathrm{x}$ & & $\hat{x}$ & $Q>F$ & $\hat{x}$ & tr. & & & & $\hat{x}$ & & $\mathrm{x}$ & & \\
\hline 292.5 & $27-3,53-54$ & $\hat{x}$ & & $\hat{x}$ & & $\hat{x}$ & $\mathrm{Q}=\mathrm{F}$ & $\hat{x}$ & $x$ & & tr. & $\mathrm{x}$ ? & $\hat{x}$ & & & & \\
\hline 298.3 & $27-7,30-32$ & $\hat{\mathbf{x}}$ & & $\hat{x}$ & & $\hat{x}$ & $\mathrm{Q}>\mathrm{F}$ & $\hat{x}$ & $\hat{\text { tr. }}$. & & $\mathrm{x}$ & & $\hat{x}$ & & $\mathrm{x}$ & & \\
\hline 303.6 & $28-4,58-60$ & $\hat{x}$ & & $\hat{x}$ & & $\hat{x}$ & $\mathrm{Q}>\mathrm{F}$ & $\hat{x}$ & tr. & & $\hat{x}$ & & $\hat{x}$ & & $\hat{x}$ & & \\
\hline 306.0 & $28-5,140-150$ & $\hat{x}$ & & $\hat{x}$ & & $\hat{x}$ & $\mathrm{Q} \geq \mathrm{F}$ & $\hat{x}$ & & & $\hat{x}$ & & $\hat{x}$ & & & $\mathrm{x}$ & \\
\hline 318.0 & $30-1,47-48$ & $\hat{x}$ & & $\hat{x}$ & & $\hat{x}$ & $\mathrm{O}>\mathrm{F}$ & $\hat{\mathrm{tr}}$. & tr. & & & & $\hat{x}$ & & & & Very small amounts of clay minerals \\
\hline 322.7 & $30-4,64-66$ & $\ddot{x}$ & & $\ddot{x}$ & & $\mathrm{x}$ & $Q>F$ & tr. & tr. & & $\mathrm{x}$ & & $x x$ & & tr. & & Laminated sample; not much clay minerals \\
\hline $\begin{array}{l}\text { Thin sill } \\
346.3 \\
\text { Sill }\end{array}$ & $33-1,29-31$ & $\mathrm{x}$ & & $x x$ & $\mathrm{x}$ & & $\mathrm{Q}>\mathrm{F}$ & $x$ & tr. & & & $\mathrm{x}$ & & & & & Sample between two sills. $S=100 \%$ expandable layers and very well crystallized \\
\hline
\end{tabular}
Note: $\mathrm{Q}=$ quartz, $\mathrm{A}=$ opal- $\mathrm{A}, \mathrm{F}=$ feldspars $(\mathrm{Pl}=$ plagioclase, $\mathrm{AF}=$ alkali feldspar $), \mathrm{S}=$ smectite, $\mathrm{I}=$ illite, $\mathrm{Ch}=$ chlorite, $\mathrm{K}=$ kaolinite, $\mathrm{Cpt}=$ clinoptilolite, $\mathrm{Am}=$ analcime, $\mathrm{C}=$ calcite, $\mathrm{Sd}=$ siderite, tr. $=$ traces, $\mathrm{X}=$ common, $\mathrm{XX}=$ abundan 
APPENDIX C

X-Ray Diffraction Data, Site 478

\begin{tabular}{|c|c|c|c|c|c|c|c|c|c|c|c|c|c|c|c|c|c|}
\hline \multirow{2}{*}{$\begin{array}{l}\text { Sub-bottom } \\
\text { Depth (m) }\end{array}$} & \multirow{2}{*}{$\begin{array}{c}\text { Core/Section } \\
\text { (interval in } \mathrm{cm} \text { ) }\end{array}$} & \multicolumn{2}{|c|}{ Feldspars } & \multicolumn{3}{|c|}{ Silica } & \multirow[b]{2}{*}{$\mathrm{Q}: \mathrm{F}$} & \multicolumn{3}{|c|}{ Clay Minerals } & \multicolumn{2}{|c|}{ Zeolites } & \multicolumn{2}{|c|}{ Carbonates } & \multirow[b]{2}{*}{ Pyrite } & \multirow{2}{*}{$\begin{array}{l}\text { Gypsum or } \\
\text { Anhydrite }\end{array}$} & \multirow[b]{2}{*}{ Notes } \\
\hline & & $\mathrm{Pl}$ & $\overline{\mathrm{AF}}$ & $Q$ & Opal-CT & A & & $s$ & 1 & $\mathrm{Ch} / \mathrm{K}$ & $\mathrm{Cpt}$ & $\mathrm{Am}$ & $\mathrm{C}$ & $\mathrm{D}$ & & & \\
\hline 0.5 & $1-1,50-54$ & $\mathrm{x}$ & & $\mathrm{x}$ & & $x x$ & $\mathrm{Q}>\mathrm{F}$ & $\mathrm{x}$ & $\mathrm{x}$ & $\mathrm{x}$ & & & $\mathrm{x}$ & & $\mathrm{x}$ & & \\
\hline 1.1 & $1-1,109-111$ & $\hat{x}$ & & $\hat{x}$ & & $x x$ & $Q>F$ & $\mathrm{x}$ & $\mathrm{x}$ & $\mathrm{x}$ & & & $\hat{x}$ & & $\hat{x}$ & & \\
\hline 2.2 & $1-2,66-68$ & $\hat{x}$ & $\mathrm{x}$ & $\hat{x}$ & & $\mathrm{xx}$ & $Q=F$ & $\mathrm{x}$ & $\mathrm{x}$ & $\mathrm{x}$ & & & $\hat{x}$ & & $\hat{x}$ & & \\
\hline 2.4 & $1-2,90-97$ & $\hat{x}$ & & $\hat{x}$ & & $\hat{x}$ & $Q>F$ & $\hat{x}$ & tr. & & tr. & & $x x$ & & $\hat{x}$ & & Detrital clay minerals, $\mathrm{S} \approx 75 \%$ expandable layers in $\mathrm{S} / \mathrm{I}$ \\
\hline 4.9 & $2-1,136-138$ & $\hat{x}$ & & $\hat{x}$ & & $\hat{x}$ & $Q<F$ & $\hat{x}$ & tr. & tr. & tr. & & $\mathrm{xx}$ & & $\hat{x}$ & & \\
\hline 7.5 & $2-3,100-102$ & $\mathrm{x}$ & $\mathrm{x}$ & $\mathrm{x}$ & & $x x$ & $Q \leq F$ & $\mathrm{x}$ & $\mathrm{x}$ & $\ddot{x}$ & $\mathrm{x}$ & & tr. & & & & \\
\hline 9.2 & $2-4,120-122$ & $\mathrm{x}$ & & $\mathrm{x}$ & & $\mathrm{xx}$ & $\mathrm{Q} \leq \mathrm{F}$ & $\mathrm{x}$ & $\mathrm{x}$ & $\mathrm{x}$ & $\hat{x}$ & & tr. & & & & \\
\hline 10.2 & $2-5,69-71$ & $\mathrm{x}$ & & $\hat{x}$ & & $\mathrm{xx}$ & $Q \cong F$ & $\mathrm{x}$ & $\mathrm{x}$ & & $\mathrm{x}$ & & $\mathrm{x}$ & & & & Relatively much clinoptilolite \\
\hline 11.3 & $2-6,82-84$ & $\hat{x}$ & & $\mathrm{x}$ & & $x \mathrm{x}$ & $Q \geq F$ & $\mathrm{x}$ & tr. & & & & $\mathrm{x}$ & & & & \\
\hline 13.5 & $3-1,49-51$ & $\hat{x}$ & $\mathrm{x}$ & $\hat{x}$ & & $x \mathrm{x}$ & $Q=F$ & $\mathrm{x}$ & tr. & & & & $\hat{x}$ & & & & \\
\hline 16.7 & $3-3,72-74$ & $\ddot{x}$ & & $\mathrm{x}$ & & $\mathrm{x}$ & $Q>F$ & $\mathrm{x}$ & tr. & & $\mathrm{x}$ & & $\hat{x}$ & & $\mathrm{x}$ & & \\
\hline 23.1 & $4-1,59-61$ & tr. & & $\mathrm{xx}$ & & $\mathrm{x}$ & $Q>F$ & $\mathrm{x}$ & $\mathrm{x}$ & & $\hat{x}$ & & tr. & & $\hat{x}$ & $\mathrm{x}$ & \\
\hline 26.5 & $4-3,98-100$ & $\mathrm{x}$ & & $\mathrm{x}$ & & $\mathrm{x}$ & $Q=F$ & $\mathrm{x}$ & $\mathrm{x}$ & & $\mathrm{x}$ & & $\mathrm{x}$ & & & & $\mathrm{S}=75 \%$ expandable layers $\mathrm{S} / \mathrm{I}$ \\
\hline 29.3 & $4-5,82-84$ & $\mathrm{x}$ & $\mathrm{x}$ & $\ddot{x}$ & & $\hat{x}$ & $\mathrm{Q}>\mathrm{F}$ & $\mathrm{x}$ & $\mathrm{x}$ & $\mathrm{x}$ & $\mathrm{x}$ & & & & & & \\
\hline 30.9 & $4-6,93-95$ & $\mathrm{x}$ & $\mathrm{x}$ & $\mathrm{x}$ & & $\mathrm{xx}$ & $Q>F$ & $\mathrm{x}$ & tr. & tr. & $\mathrm{x}$ & & $\mathrm{x}$ & & & $\mathrm{x}$ & \\
\hline 33.3 & $5-1,130-135$ & $\mathrm{x}$ & $\mathrm{x}$ & $\mathrm{x}$ & & $\mathrm{xx}$ & $\mathrm{Q}>\mathrm{F}$ & $\mathrm{x}$ & tr. & tr. & $\mathrm{x}$ & & $\mathrm{x}$ & & & $\mathrm{x}$ & \\
\hline 34.3 & $5-2,75-77$ & $\mathrm{x}$ & & $\mathrm{x}$ & & $\mathrm{x}$ & $\mathrm{Q}>\mathrm{F}$ & $\mathrm{x}$ & $\mathrm{x}$ & $\mathrm{x}$ & $\mathrm{x}$ & & $\mathrm{x}$ & & $\mathrm{x}$ & & \\
\hline 39.9 & $5-6,40-42$ & $\mathrm{x}$ & & $\mathrm{x}$ & & $\mathrm{x}$ & $Q>F$ & $\mathrm{x}$ & $\mathrm{x}$ & $\mathrm{x}$ & $\mathrm{x}$ & & $\mathrm{x}$ & & $\mathrm{x}$ & & Some amphibole \\
\hline 41.9 & $6-1,43-45$ & $\mathrm{x}$ & & $\mathrm{x}$ & & $\mathrm{x}$ & $Q>F$ & $\mathrm{x}$ & $\mathrm{x}$ & $\mathrm{x}$ & $\mathrm{x}$ & & $\mathrm{x}$ & & $\mathrm{x}$ & & Some amphibole \\
\hline 43.7 & $6-2,69-71$ & $\mathrm{x}$ & & $\mathrm{x}$ & & $\mathrm{x}$ & $Q>F$ & $\mathrm{x}$ & tr. & tr. & $\mathrm{x}$ & & & & $\mathrm{x}$ & $\mathrm{x}$ & Relatively much clinoptilolite \\
\hline 46.8 & $6-4,81-83$ & $\hat{x}$ & $\mathrm{x}$ & $\hat{x}$ & & $\hat{x}$ & $Q>F$ & $\hat{x}$ & tr. & tr. & $\hat{\mathrm{tr}}$. & & $\mathrm{x}$ & & $\hat{x}$ & & \\
\hline 47.8 & $6-5,27-29$ & $\hat{x}$ & & $\hat{x}$ & & $\mathrm{xx}$ & $Q>F$ & $\hat{\text { tr. }}$ & tr. & tr. & tr. & & & & $\mathrm{A}$ & & \\
\hline 48.0 & $6-5,51-52$ & $\hat{x}$ & & $\hat{x}$ & & 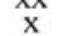 & $\mathrm{Q}<\mathrm{F}$ & 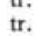 & $\mathrm{x}$ & & tr. & & & & $\mathrm{x}$ & & \\
\hline $\begin{array}{l}48.0 \\
56.3\end{array}$ & $\begin{array}{l}0-3,51-32 \\
7-4,79-81\end{array}$ & $\begin{array}{l}x \\
x\end{array}$ & & $\begin{array}{l}x \\
x\end{array}$ & & $\begin{array}{l}x \\
x\end{array}$ & $Q>F$ & 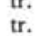 & tr. & tr. & & & $\mathrm{xx}$ & & $\hat{x}$ & & \\
\hline 59.3 & $7-6,82-84$ & $\hat{x}$ & & $\hat{x}$ & & $\hat{x}$ & $Q=F$ & $\mathrm{x}$ & tr. & & $\mathrm{x}$ & & $\mathrm{x}$ & & & & \\
\hline 60.3 & $7-7,28-30$ & $\hat{x}$ & & $\hat{x}$ & & $\hat{x x}$ & $Q>F$ & $\hat{x}$ & $\mathrm{x}$ & & & & $\hat{x}$ & & & & \\
\hline 61.6 & $8-1,104-106$ & $\hat{x}$ & & $\hat{x}$ & & $\mathrm{x}$ & $Q>F$ & $\hat{x}$ & $\hat{x}$ & & $\mathrm{x}$ & & $\mathrm{x}$ & & $\mathrm{x}$ & & \\
\hline 64.6 & $8-3,112-114$ & $\hat{x}$ & & $\hat{x}$ & & $\hat{x}$ & $Q>F$ & $\hat{x}$ & $\hat{x}$ & $\mathrm{x}$ & $\hat{x}$ & & & & $\hat{x}$ & & \\
\hline 74.7 & $9-4,15-17$ & $\mathrm{x}$ & & $\mathrm{x}$ & & $\mathrm{x}$ & $Q>F$ & $\mathrm{x}$ & $\mathrm{x}$ & $\mathrm{x}$ & $\mathrm{x}$ & & $\mathrm{x}$ & & $\mathrm{x}$ & & \\
\hline 81.4 & $10-2,43-45$ & $\mathrm{x}$ & & $\mathrm{x}$ & & $\hat{x}$ & $\mathrm{Q}>\mathrm{F}$ & $\mathrm{x}$ & $\mathrm{x}$ & & $\mathrm{x}$ & & $\mathrm{x}$ & & $\mathrm{x}$ & & \\
\hline 91.6 & $11-2,106-108$ & $\mathrm{x}$ & & $x$ & & $\mathrm{x}$ & $Q>F$ & $\mathrm{x}$ & $\mathrm{x}$ & & $\mathrm{x}$ & & $\mathrm{x}$ & & $\mathrm{x}$ & & \\
\hline 96.6 & $11-6,50-52$ & $\mathrm{x}$ & & $\mathrm{x}$ & & $x x$ & $Q>F$ & $\mathrm{x}$ & $\mathrm{x}$ & $\mathrm{x}$ & $\mathrm{x}$ & & & & & & \\
\hline 104.1 & $12-4,104-106$ & $\mathrm{x}$ & $\mathrm{x}$ & $\mathrm{x}$ & & $x x$ & $Q>F$ & $\mathrm{x}$ & $\mathrm{x}$ & $\mathrm{x}$ & $\mathrm{x}$ & & $\mathrm{x}$ & & & & \\
\hline 113.5 & $13-4,102-104$ & $\mathrm{x}$ & $\hat{x}$ & $\hat{x}$ & & $x x$ & $Q>F$ & $\mathrm{x}$ & $\mathrm{x}$ & $\mathrm{x}$ & $\mathrm{x}$ & & $\mathrm{x}$ & & & & \\
\hline 124.9 & $14-5,138-140$ & $\hat{x}$ & & $\hat{x}$ & & $\mathrm{x}$ & $Q>F$ & $\hat{x}$ & $\hat{\text { tr. }}$ & & & & $\hat{x}$ & $\mathrm{x}$ & & $\mathrm{x}$ & Some protodolomite \\
\hline 132.8 & $15-4,133-135$ & $\hat{x}$ & & $\hat{x}$ & & $\hat{x}$ & $Q>F$ & $\hat{\text { tr. }}$ & tr. & & $\mathrm{x}$ & & $\hat{x}$ & $\hat{\mathrm{x}}$ ? & $\mathrm{x}$ & & \\
\hline 140.1 & $\begin{array}{l}16-4,133-135 \\
16-3,63-65\end{array}$ & $\begin{array}{l}\hat{x} \\
x\end{array}$ & & $\hat{x}$ & & $\begin{array}{l}x \\
x\end{array}$ & $Q>F$ & $\mathrm{x}$ & $x$ & $\mathrm{x}$ & $\hat{x}$ & & $\hat{x}$ & & $\hat{x}$ & & \\
\hline $\begin{array}{l}140.1 \\
151.5\end{array}$ & $\begin{array}{l}10-3,3,97-63 \\
17-4,97-99\end{array}$ & $\begin{array}{l}x \\
x\end{array}$ & & $\hat{x}$ & & $\begin{array}{l}\lambda \\
x\end{array}$ & $Q>F$ & $\hat{x}$ & $\hat{x}$ & $\hat{x}$ & $\hat{x}$ & & $\begin{array}{l}\hat{\text { tr. }} \\
\text {. }\end{array}$ & & $\hat{x}$ & & \\
\hline 155.7 & $18-1,14-18$ & $\hat{x}$ & $\mathrm{x}$ & $\hat{x}$ & & tr. & $Q=F$ & tr. & tr. & & & & & & & & Mainly quartz and two feldspars \\
\hline 168.8 & $19-7,24-26$ & $\hat{x}$ & & $\hat{x}$ & & $\mathrm{x}$ & $Q>F$ & $\mathrm{x}$ & tr. & & $\mathrm{x}$ & & tr. & & $\mathrm{x}$ & & \\
\hline 179.3 & $21-4,30-32$ & $\hat{x}$ & & $\hat{x}$ & & $\hat{x x}$ & $Q>F$ & $\hat{x}$ & $\mathrm{x}$ & tr. & $\hat{x}$ & & $\mathrm{x}$ & & $\hat{x}$ & $\mathrm{x}$ & \\
\hline 182.6 & $21-6,55-57$ & $\hat{x}$ & & $\hat{x}$ & & $\hat{x} \hat{x}$ & $Q>F$ & $\hat{x}$ & & & $\hat{\text { tr. }}$ & & $\hat{x}$ & & & $\hat{x}$ & \\
\hline 184.9 & $22-1,93-95$ & $\hat{x}$ & & $\hat{x}$ & & $\mathrm{x}$ & $Q>F$ & $\hat{x}$ & tr. & tr. & $x$ & & $\hat{x}$ & & $\mathrm{x}$ & $\hat{x}$ & \\
\hline 186.5 & $22-2,103-105$ & $\mathrm{x}$ & & $\mathrm{x}$ & & $\mathrm{x}$ & $Q>F$ & $\mathrm{x}$ & tr. & tr. & $\mathrm{x}$ & & $\mathrm{x}$ & & $\hat{x}$ & tr. & \\
\hline 188.2 & $22-3,116-118$ & $\hat{x}$ & & $\hat{x}$ & & $\hat{x}$ & $Q>F$ & $\mathrm{x}$ & tr. & tr. & $\mathrm{x}$ & & $\mathrm{x}$ & & $\mathrm{x}$ & $\mathrm{x}$ & \\
\hline 188.5 & $22, \mathrm{CC}(0-3)$ & & & $\hat{x}$ & & & & & & & & & & $x x$ & & & Mainly dolomite \\
\hline 189.0 & $22, \mathrm{CC}(3-8)$ & $\mathrm{x}$ & & $\mathrm{x}$ & & & $\mathrm{Q} \simeq \mathrm{F}$ & tr. & tr. & & $\mathrm{x}$ & & & $\mathrm{x}$ & & & Dolomite with distinct order reflections \\
\hline 203.5 & $24-1,0-4$ & $\mathrm{x}$ & & $\mathrm{x}$ & & & $Q=F$ & tr. & tr. & & $\mathrm{xX}$ & & & $\mathrm{x}$ & $\mathrm{x}$ & & Dolomite with distinct order reflections. Much clinoptilolite \\
\hline Sill & $280-29-31$ & & & & & & & & & & & & & & & & \\
\hline $\begin{array}{l}241.3 \\
241.3\end{array}$ & $\begin{array}{l}28-0,29-31 \\
28-0,33-35\end{array}$ & $\begin{array}{l}x \\
x\end{array}$ & & $\begin{array}{l}x \\
x\end{array}$ & & $\begin{array}{l}\mathrm{x} \\
\mathrm{x}\end{array}$ & $\begin{array}{l}Q \simeq F \\
Q \simeq F\end{array}$ & $\begin{array}{l}x \\
x\end{array}$ & $\begin{array}{l}\text { tr. } \\
\text { tr. }\end{array}$ & $\begin{array}{l}\text { tr. } \\
\text { tr. }\end{array}$ & $\begin{array}{l}x \\
x\end{array}$ & & $\begin{array}{l}x \\
x\end{array}$ & & $\begin{array}{l}\mathrm{X} \\
\mathrm{x}\end{array}$ & $\begin{array}{l}x \\
x\end{array}$ & $S=100 \%$ expandahle layers \\
\hline 242.8 & $28-1,31-34$ & $\begin{array}{l}x \\
x\end{array}$ & & $\begin{array}{l}x \\
x\end{array}$ & & $\begin{array}{l}x \\
x\end{array}$ & $Q \simeq F$ & $\begin{array}{l}x \\
x\end{array}$ & $\begin{array}{l}\text { tr. } \\
\text { tr. }\end{array}$ & $\begin{array}{l}\text { tr. } \\
\text { tr. }\end{array}$ & $\begin{array}{l}x \\
x\end{array}$ & & $\hat{x}$ & & $\hat{x}$ & $\hat{x}$ & \\
\hline
\end{tabular}




\begin{tabular}{|c|c|c|c|c|c|c|c|c|c|c|c|c|c|c|c|c|c|}
\hline 243.7 & $28-1,117-119$ & $\mathrm{x}$ & & $\mathrm{x}$ & & $\mathrm{x}$ & $Q \simeq F$ & $\mathrm{x}$ & tr. & tr. & $\mathrm{x}$ & & $\mathrm{x}$ & & $\mathrm{x}$ & & \\
\hline 244.1 & $28-2,8-10$ & $\mathrm{x}$ & & $\mathrm{x}$ & & $\mathrm{x}$ & $Q=F$ & $\mathrm{x}$ & tr. & tr. & & & $\mathrm{x}$ & & $\mathrm{x}$ & $\mathrm{x}$ & \\
\hline 244.2 & $28-2,23-25$ & $\mathrm{x}$ & & $\mathrm{x}$ & & $\mathrm{x}$ & $Q \simeq F$ & $\mathrm{x}$ & tr. & & tr. & & $\mathrm{x}$ & & $\mathrm{x}$ & tr. & \\
\hline 245.2 & $28-2,122-124$ & $\hat{x}$ & & $\hat{x}$ & & $\hat{x}$ & $Q \simeq F$ & $\hat{\mathrm{x}}$ & tr. & & $\mathrm{x}$ & & $\mathrm{x}$ & & $\mathrm{x}$ & $\mathrm{x}$ & \\
\hline 245.9 & $28-3,35-37$ & $\hat{x}$ & & $\mathrm{x}$ & & $\hat{x}$ & $\mathrm{Q} \approx \mathrm{F}$ & tr. & tr. & & tr. & & $\mathrm{x}$ & $\mathrm{x}$ & $\mathrm{x}$ & $\mathrm{x}$ & \\
\hline 246.9 & $28-3,139-141$ & $\hat{x}$ & & $\hat{x}$ & & $\hat{x x}$ & $\mathrm{Q} \leq \mathrm{F}$ & $\mathrm{x}$ & $\mathrm{x}$ & & & & $\hat{x}$ & & $\mathrm{x}$ & & Well-crystallized illite \\
\hline 247.2 & $28-4,23-25$ & $\mathrm{x}$ & $\mathrm{x}$ & $\mathrm{x}$ & & $\hat{x}$ & $\mathrm{O}>\mathrm{F}$ & $\hat{x}$ & $\hat{\text { tr. }}$ & & & & $\hat{x}$ & & $\hat{x}$ & $\mathrm{x}$ & \\
\hline 248.8 & $28-5,31-33$ & $\hat{x}$ & $\hat{x}$ & $\hat{x}$ & & $\hat{x}$ & $\mathrm{O}>\mathrm{F}$ & $\hat{x}$ & tr. & & & & & & $\hat{x}$ & tr. & $\mathrm{S} \simeq 80 \%$ expandable layers in $\mathrm{S} / \mathrm{I}$ \\
\hline 249.6 & $28-6,6-8$ & $\mathrm{x}$ & $\mathrm{x}$ & $\hat{x}$ & & $\mathrm{x}$ & $O>F$ & $\hat{x}$ & tr. & & $\mathrm{x}$ & & $\mathrm{x}$ & & $\mathrm{x}$ & tr. & \\
\hline 250.0 & $28-6,52-54$ & $\hat{x}$ & & $\hat{x}$ & & $\hat{x}$ & $\mathrm{O} \geq \mathrm{F}$ & $\hat{x}$ & $\mathrm{x}$ & & $\hat{x}$ & & $\hat{x}$ & & & $x$ & \\
\hline 250.6 & $28-6,105-107$ & $\hat{x}$ & & $\hat{x}$ & & $\hat{x x}$ & $Q<F$ & $\hat{x}$ & $\mathrm{x}$ & $\mathrm{x}$ & $\hat{x}$ & & $\hat{x}$ & & $\mathrm{x}$ & & \\
\hline 250.8 & $29-1,26-28$ & $\hat{x}$ & $\mathrm{x}$ & $\hat{x}$ & & $\mathrm{x}$ & $Q>F$ & $\hat{x}$ & $\hat{\mathrm{tr}}$. & & $\hat{x}$ & & $\hat{x}$ & & $\hat{x}$ & & \\
\hline 252.3 & $29-2,25-26$ & $\hat{x}$ & $\hat{x}$ & $\hat{x}$ & & $\hat{x}$ & $Q>F$ & $\hat{x}$ & $\begin{array}{l}\text { tr. } \\
\text {. }\end{array}$ & & $\hat{x}$ & & $\hat{x}$ & & $\hat{x}$ & $\mathrm{x}$ & Much gypsum and much pyrite \\
\hline 252.5 & $29-2,48-50$ & $\hat{x}$ & & $\hat{x}$ & $\mathrm{xx}$ & tr. & $Q>F$ & $\hat{x}$ & tr. & & & & $\hat{x}$ & & $\hat{x}$ & tr. & Much opal-CT; abundant pyrite \\
\hline $\begin{array}{l}252.5 \\
253.1\end{array}$ & $\begin{array}{l}29-2,48-50 \\
29-2,104-107\end{array}$ & $\begin{array}{l}x \\
x\end{array}$ & & $\begin{array}{l}x \\
x\end{array}$ & $\begin{array}{l}x x \\
x x \\
x\end{array}$ & tr. & $\begin{array}{l}Q \\
Q \geq F\end{array}$ & $\begin{array}{l}x \\
x\end{array}$ & $\begin{array}{l}\text { tr. } \\
\text { tr. }\end{array}$ & & & $\mathrm{x}$ & $\begin{array}{l}x \\
x\end{array}$ & & $\begin{array}{l}x \\
x\end{array}$ & $\stackrel{\text { tr. }}{x}$ & $\begin{array}{l}\text { Much opal-C1; abunaant pyrite } \\
\text { Much opal-CT; } S=100 \% \text { expandable layers; analcime }\end{array}$ \\
\hline 253.3 & $\begin{array}{l}29-2,104-107 \\
29-2,132-134\end{array}$ & $\begin{array}{l}x \\
x\end{array}$ & & $\begin{array}{l}x \\
x x\end{array}$ & 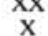 & & $\begin{array}{l}Q=F \\
Q \geq F\end{array}$ & $\underset{x}{x}$ & & & & $x$ & $x$ & & $\begin{array}{l}x \\
x\end{array}$ & $x$ & Less opal-CT; $\mathrm{S}=100 \%$ expandable layers and well crystallized \\
\hline Sill & $29-2,132-134$ & $x$ & & $x x$ & & & & & & & & & & & & & 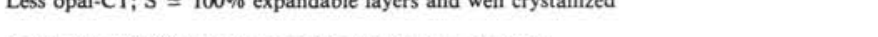 \\
\hline 256.9 & $30-1,35-37$ & $\mathrm{x}$ & & $\mathrm{x}$ & $x x$ & tr. & $\mathrm{Q} \approx \mathrm{F}$ & tr. & tr. & & $\mathrm{xx}$ & & & & $\mathrm{x}$ & & Much clinoptilolite; much opal-CT; relatively much pyrite \\
\hline 257.3 & $30-1,73-78$ & $\mathrm{x}$ & & $\mathrm{x}$ & $\mathrm{Xx}$ & tr. & $Q>F$ & tr. & tr. & & & & $\mathrm{x}$ & $\mathrm{X}$ ? & & tr. & Much opal-CT \\
\hline 258.1 & $30-2,10-12$ & $\hat{x}$ & & $\hat{x}$ & $\begin{array}{l}x \times \\
x ?\end{array}$ & $\mathrm{x}$ & $Q \cong F$ & $\mathrm{x}$ & 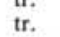 & & & & $\hat{x}$ & $\mathrm{Al}$ : & $\mathrm{x}$ & tr. & \\
\hline 259.0 & $30-2,94-96$ & $\mathrm{x}$ & & $\mathrm{x}$ & & $\mathrm{x}$ & $Q>F$ & $\mathrm{x}$ & tr. & & $\mathrm{x}$ & & $\mathrm{x}$ & & $\mathrm{x}$ & & \\
\hline 259.5 & $30, \mathrm{CC}$ & $\mathrm{x}$ & & $\mathrm{x}$ & & $\mathrm{x}$ & $Q-F$ & $\mathrm{x}$ & tr. & & $\mathrm{x}$ & & $\mathrm{x}$ & & $\mathrm{x}$ & & $\mathrm{S}=70 \%$ expandable layers in $\mathrm{S} / 1$ \\
\hline 260.5 & $31-1,46-48$ & $\mathrm{x}$ & & $\hat{x}$ & & $\mathrm{x}$ & $Q=F$ & $\mathrm{x}$ & $\mathrm{x}$ & & & & $\mathrm{x}$ & & $\mathrm{x}$ & $\mathrm{x}$ & \\
\hline 261.4 & $31-1,142-144$ & $\mathrm{x}$ & & $\hat{x}$ & & $\hat{x}$ & $Q>F$ & $\mathrm{x}$ & $\mathrm{x}$ & tr. & $\mathrm{x}$ & & & & & tr. & \\
\hline 263.7 & $31-3,64-66$ & $\mathrm{x}$ & & $\mathrm{x}$ & & $\mathrm{x}$ & $Q>F$ & $\mathrm{x}$ & $\mathrm{x}$ & tr. & $\mathrm{x}$ & & $\mathrm{x}$ & & & & \\
\hline 267.2 & $31-5,117-119$ & $\mathrm{x}$ & & $\mathrm{x}$ & & $\mathrm{x}$ & $Q>F$ & $\mathrm{x}$ & $\mathrm{x}$ & tr. & $\mathrm{x}$ & & $\mathrm{x}$ & & & & \\
\hline 273.0 & $32-3,46-48$ & $\mathrm{x}$ & & $\mathrm{x}$ & & $\mathrm{x}$ & $Q>F$ & $\mathrm{x}$ & $\mathrm{x}$ & tr. & $\mathrm{x}$ & & $\mathrm{x}$ & & $\mathrm{x}$ & & \\
\hline 282.5 & $33-3,50-52$ & $\mathrm{x}$ & & $\mathrm{x}$ & & $\mathrm{x}$ & $Q>F$ & $\mathrm{x}$ & $\mathrm{x}$ & tr. & $\mathrm{x}$ & & $\mathrm{x}$ & & $\hat{x}$ & & \\
\hline 288.8 & $34-1,29-31$ & $\mathrm{x}$ & & $\mathrm{x}$ & & tr. & $Q>F$ & $\mathrm{x}$ & tr. & & & & $\mathrm{x}$ & $\mathrm{X}$ ? & $\hat{x}$ & $\mathrm{x}$ & \\
\hline 292.4 & $34-3,88-90$ & $\mathrm{x}$ & & $\hat{x}$ & & tr. & $Q>F$ & $\mathrm{x}$ & tr. & & & & $\hat{x}$ & $\mathrm{x}$ ? & $\mathrm{x}$ & tr. & \\
\hline 298.4 & $35-1,38-39$ & $\hat{x}$ & & $\hat{x}$ & & tr. & $Q>F$ & $\mathrm{x}$ & tr. & & & & $\mathrm{x}$ & $\mathrm{x}$ & $\hat{x}$ & $x$ & \\
\hline 303.4 & $35-4,86-87$ & $\hat{x}$ & & $\hat{x}$ & & tr. & $Q>F$ & tr. & tr. & & & & & $\hat{x x}$ & & $\hat{x}$ & Protodolomite is main phase \\
\hline 304.4 & $35-5,35-37$ & $\hat{x}$ & & $\hat{x}$ & & x. & $Q \approx F$ & $\mathrm{x}$ & tr. & tr. & & & $x x$ & & $\mathrm{x}$ & & (1) \\
\hline 309.1 & $36-2,7-9$ & $\hat{t r}$. & & $\hat{x}$ & & $\hat{x}$ & $Q>F$ & $\hat{x}$ & tr. & tr. & & & $x \mathrm{x}$ & & $\hat{x}$ & & \\
\hline 309.4 & $36-2,41-43$ & $x$ & & $\hat{x}$ & & $\hat{\text { tr. }}$. & $Q>F$ & $\hat{x}$ & tr. & & & & $\mathrm{x}$ & $\mathrm{x}$ & $\hat{x}$ & $\mathrm{x}$ & \\
\hline 310.0 & $36-2,94-95$ & $\hat{x}$ & & $\hat{x}$ & & tr. & $\mathrm{Q}>\mathrm{F}$ & tr. & tr. & & & & $\hat{x}$ & & $\mathrm{x}$ & & \\
\hline 329.1 & $39-2,107-108$ & $\hat{\text { tr. }}$ & & $\hat{x}$ & $\mathrm{x}$ & & $Q>F$ & tr. & tr. & & & & $\hat{x}$ & & $\hat{x}$ & tr. & \\
\hline 330.0 & $39-3,44-46$ & $x$ & & $\hat{x}$ & $\hat{x}$ & & $Q>F$ & tr. & tr. & & tr. & & $\mathrm{x}$ & & $\hat{x}$ & tr. & Opal-CT $=$ quartz \\
\hline 336.0 & $40-1,3-4$ & $\hat{x}$ & & $\hat{x}$ & $\hat{x}$ & & $Q=F$ & $\mathrm{x}$ & tr. & & w. & & $\hat{\text { tr. }}$. & & & $x$ & 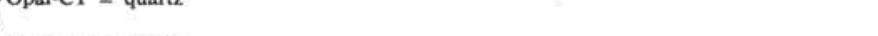 \\
\hline 336.2 & $40-1,19-21$ & $\hat{x}$ & & $\hat{x x}$ & $\hat{x}$ & & $Q>F$ & $\mathrm{x}$ & & & & & $\mathrm{x}$ & & $\mathrm{x}$ & $\mathrm{x}$ & Opal-CT < quartz \\
\hline 337.2 & $40-1,118-120$ & $\hat{x}$ & & $\hat{x} \hat{x}$ & & & $\mathrm{Q} \geq \mathrm{F}$ & tr. & tr. & & & & & & $x x$ & tr. & Mainly quartz and feldspar; much pyrite; no opal-CT \\
\hline 337.9 & $40-2,40-42$ & $\hat{x}$ & & $\begin{array}{l}x x \\
x x\end{array}$ & & & $Q \geq F$ & $\mathrm{x}$ & tr. & & & & $\mathrm{x}$ & & $\mathrm{xx}$ & $\mathrm{x}$ & Mainly quartz and feldspar; much pyrite; no opal-CT \\
\hline 338.5 & $40-2,90-99$ & $\hat{x}$ & & $\hat{x} \hat{x}$ & & & $Q>F$ & $\hat{\mathrm{x}}$ & tr. & & & & $\mathrm{x}$ & & $\mathrm{x}$ & $\hat{x}$ & Mainly quartz and feldspars; clay crystallinity increases \\
\hline 338.78 & $40-2,128-129$ & $\hat{\mathrm{x}}$ & & $\hat{x} x$ & & & $Q>F$ & $\hat{x}$ & $\mathrm{x}_{\mathrm{x}}^{\mathrm{T}}$ & & & & & & $\hat{\text { tr. }}$ & $\hat{x}$ & Mainly quartz and feldspars; clay crystallinity increases \\
\hline 338.82 & $40-2,132-133$ & $\hat{\mathrm{x}}$ & & $\hat{x}$ & & & $Q \geq F$ & $\hat{x}$ & $\hat{\mathrm{x}}$ & & & & $\mathrm{x}$ & & tr. & & $S$ and 1 are well crystallized. $S \simeq 100 \%$ expandable layers. \\
\hline 338.87 & $40-2,137-138$ & $\mathrm{x}$ & & $\mathrm{x}$ & & & $Q \approx F$ & $\mathrm{xx}$ & & & & & & & & $\mathrm{x}$ & Much well-crystallized $S \simeq 100 \%$ expandable layers. This sam \\
\hline 338.92 & $40-2,141-143$ & $\mathrm{x}$ & & $\mathrm{x}$ & & & $Q \leq F$ & $x \mathrm{x}$ & & & & & & & & $\hat{\mathrm{x}}$ & Much well-crystallized $\mathrm{S} \cong 100 \%$ expandable layers. This sample is mixed with basalt pieces \\
\hline Thick sill & & & & & & & & & & & & & & & & & \\
\hline
\end{tabular}

ote: $\mathrm{Q}=$ quartz, $\mathrm{A}=$ opal- $\mathrm{A}, \mathrm{F}=$ feldspar $(\mathrm{PL}=$ plagioclase, $\mathrm{AF}=$ alkali feldspar), $\mathrm{S}=$ smectite, $\mathrm{I}=$ illite, $\mathrm{Ch}=$ chlorite, $\mathrm{K}=$ kaolinite, $\mathrm{Cpt}=$ clinoptilolite, $\mathrm{Am}=$ analcime, $\mathrm{C}=$ calcite, $\mathrm{D}=$ dolomite, tr. $=$ traces, $\mathrm{X}=$ common, $\mathrm{XX}=$ abundant. Blanks indicate that the mineral was not observed. 